\title{
Atmospheric Deposition and Critical Loads for Nitrogen and Metals in Arctic Alaska: Review and Current Status
}

\author{
Greg Linder ${ }^{1}$, William Brumbaugh ${ }^{2 *}$, Peter Neitlich ${ }^{3}$, Edward Little $^{2}$ \\ ${ }^{1}$ US Geological Survey, Brooks, OR, USA \\ ${ }^{2}$ US Geological Survey, Columbia, MO, USA \\ ${ }^{3}$ National Park Service, Winthrop, WA, USA \\ Email: *bbrumbaugh@usgs.gov
}

Received September 24, 2013; revised October 24, 2013; accepted November 1, 2013

Copyright (C) 2013 Greg Linder et al. This is an open access article distributed under the Creative Commons Attribution License, which permits unrestricted use, distribution, and reproduction in any medium, provided the original work is properly cited.

\begin{abstract}
To protect important resources under their bureau's purview, the United States National Park Service's (NPS) Arctic Network (ARCN) has developed a series of "vital signs" that are to be periodically monitored. One of these vital signs focuses on wet and dry deposition of atmospheric chemicals and further, the establishment of critical load (CL) values (thresholds for ecological effects based on cumulative depositional loadings) for nitrogen $(\mathrm{N})$, sulfur, and metals. As part of the ARCN terrestrial monitoring programs, samples of the feather moss Hylocomium splendens are being collected and analyzed as a cost-effective means to monitor atmospheric pollutant deposition in this region. Ultimately, moss data combined with refined CL values might be used to help guide future regulation of atmospheric contaminant sources potentially impacting Arctic Alaska. But first, additional long-term studies are needed to determine patterns of contaminant deposition as measured by moss biomonitors and to quantify ecosystem responses at particular loadings/ ranges of contaminants within Arctic Alaska. Herein we briefly summarize 1) current regulatory guidance related to CL values 2) derivation of CL models for $\mathrm{N}$ and metals, 3) use of mosses as biomonitors of atmospheric deposition and loadings, 4) preliminary analysis of vulnerabilities and risks associated with CL estimates for N, 5) preliminary analysis of existing data for characterization of $\mathrm{CL}$ values for $\mathrm{N}$ for interior Alaska and 6) implications for managers and future research needs.
\end{abstract}

Keywords: Critical Loads; Alaska; Arctic; Nitrogen; Metals

\section{Introduction}

The United States National Park Service's (NPS) Arctic Network (ARCN) is currently developing "vital signs" [1] that address resource management objectives under their bureau's purview. The ARCN management areas include Bering Land Bridge National Preserve, Cape Krusenstern National Monument, Gates of the Arctic National Park and Preserve, Kobuk Valley National Park, and Noatak National Preserve (Figure 1). One of the ARCN's vital signs is a multifaceted indicator, "Wet and Dry Deposition of Various Pollutants" which intends to examine airborne depositional trends and patterns, and ecological effects associated with deposition of nitrogen $(\mathrm{N})$, sulfur, metals and semi-volatile organic compounds (SVOCs).

\footnotetext{
"Corresponding author.
}

As part of the established terrestrial ARCN monitoring program, tissue samples of the moss Hylocomium splendens are being collected and analyzed to serve as biomonitors of atmospherically derived contaminants. Moreover, within an adaptive resource management context, NPS seeks to develop predictive models to characterize thresholds for ecological effects based on cumulative deposition of atmospheric contaminants, expressed as critical loads (CLs). Ultimately, moss data combined with refined CL values could be used to help guide future regulation of atmospheric contaminant sources potentially impacting Arctic Alaska; however, additional research will be needed before that can occur. Specifically, additional research is needed in two key areas: 1) more comprehensive trend monitoring to determine levels and patterns of contaminant deposition as measured by moss 


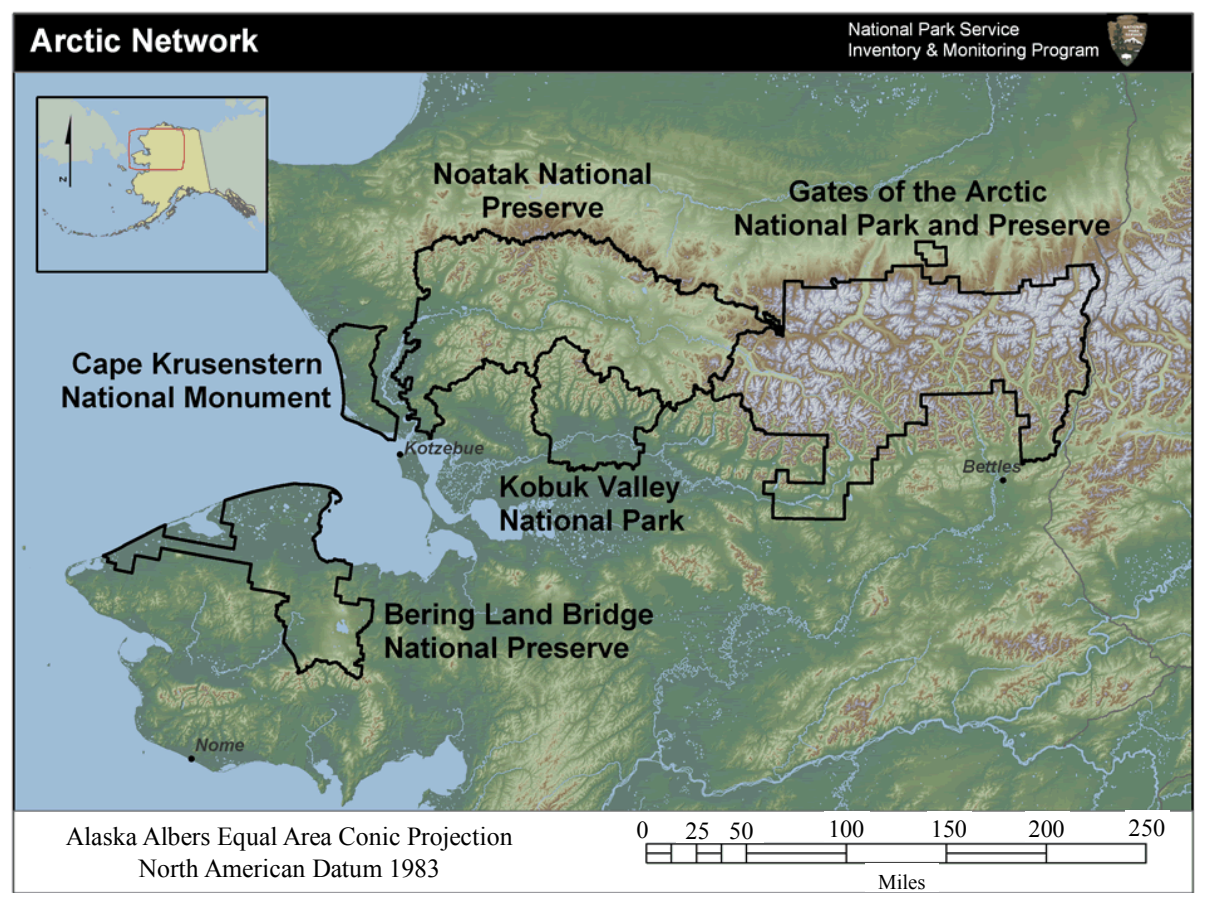

Figure 1. National Park Service lands included in the Arctic Network of Alaska.

biomonitors and 2) long-term ecological studies to establish ecosystem responses at particular loadings/ranges of contaminants to support more accurate determination of CLs. Presently, although much has been learned from past studies, the accumulation of various atmospheric contaminants by mosses and other cryptogams is not fully understood, particularly for Arctic Alaska. Consequently, comparisons between biologically incorporated contaminants in moss biomonitors and depositional loads (as measured by instrumental monitors or abiotic passive samplers); and more importantly to presumptive CLs, would enable NPS to more accurately predict the potential for ecological effects based on moss sampling. Initially, resource managers have focused on characterizing CLs for $\mathrm{N}$, but similar tools for evaluating atmospheric deposition and CLs are also being investigated for sulfur and selected metals.

Herein we briefly summarize 1) current regulatory guidance related to CL's of pollutant deposition; 2) derivation of CL models for $\mathrm{N}$ and metals; 3) use of mosses as biomonitors of atmospheric deposition or loads of nitrogen, sulfur, and metals; 4) a preliminary analysis of vulnerabilities and risks associated with CL estimates for $\mathrm{N}$; 5) a preliminary analysis of existing data for characterization of CLs for $\mathrm{N}$ at Alaska monitoring stations; and 6) implications for managers and future research needs. Our review focuses on arctic, sub-arctic, and boreal zones of Alaska which hopefully will benefit developing resource management plans reliant on monitoring activities conducted by NPS and other agencies here and elsewhere.

\section{Current Regulatory Guidance on Atmospheric Deposition and Critical Loads}

Nilsson and Grennfelt originally characterized a CL (critical load or critical level) as a "quantitative estimate of exposure to one or more pollutants below which significant harmful effects on specified sensitive elements of the environment do not occur according to present knowledge" [2]. For those atmospheric contaminants that are delivered to terrestrial habitats via wet and dry deposition, the cumulative exposure expressed as a critical "load" (in units of kilograms/hectare/year) will be most important; however, for certain gasses (e.g., ozone, sulfur dioxide, and ammonia), the average annual exposure concentration (termed a critical "level") is most relevant [3]. While sulfur oxide (SOx) emissions of have generally declined across North America in recent years, emissions of nitrogen species have increased across a wide spatial range [4]. Critical loads for nitrogen are directly linked with emissions of ammonia $\left(\mathrm{NH}_{3}\right)$ and deposition of ammonium ion $\left(\mathrm{NH}_{4}^{+}\right)$, and emissions of nitrogen oxide gasses (NOx) and deposition of nitrite and nitrate ions $\left(\mathrm{NO}_{2}^{-}\right.$ and $\mathrm{NO}_{3}^{-}$). Furthermore, increasing nitrogen loads are more often being causally linked with increased acidity and nutrient enrichment in both aquatic and terrestrial habitats. The manner which increased nitrogen loads are delivered varies spatially across North America. For example, release of ammonia and deposition of ammonium ion are associated with regionally specific applications of fertilizers and live-stock operations in agricultural areas, 
whereas nitrogen oxides tend to be more widely dispersed and are strongly linked with the burning of fossil fuels. Both short- and long-range atmospheric transport have resulted in atmospheric nitrogen deposition that has increased throughout North America.

In Europe, CLs have been commonly used to evaluate ecological effects relative to levels of contaminant deposition, including NOx, SOx, and certain metals. Under the Long-Range Trans-boundary Air Pollution convention (LRTAP), the United Nations Economic Commission for Europe (UNECE) has generated a series of reports that includes maps of CLs that have contributed to the regulation of atmospheric emissions of selected chemicals under the auspices of the 1999 Gothenburg Protocol to Abate Acidification, Eutrophication and Groundlevel Ozone [3,5]. Similarly, in the US, regulatory frameworks primarily dependent on the Clean Air Act (CAA) have contributed to the development of primary criteria for selected chemical constituents and particulates in ambient air [6].

The value that CLs bring to managing resources is increasingly apparent in the environmental literature, yet much of the regulatory focus in the US has been specified by exposure concentrations expressed as a concentration per unit volume, not on loads. Although recent regulatory reviews indicate additional technical guidance is forthcoming [7], existing ambient air criteria are characterized within the context of models similar to those deployed by industrial hygienists or human health risk assessors. Presently, primary criteria under CAA are limited to carbon monoxide, sulfur dioxide, nitrogen dioxide, ozone, particulate matter $\left(\mathrm{PM}_{10}, \mathrm{PM}_{2.5}\right)$, and lead; but again, these are largely linked to issues of human health rather than ecological effects [8]. Although atmospheric constituents regulated under CAA are relatively few in number, interested parties in both North America and Europe have refocused on ecological effects potentially linked to exposures to atmospheric chemicals beyond their inputs historically linked to acid precipitation. For example, beyond inclusion of lead $(\mathrm{Pb})$ as a criteria air pollutant in the US, both US and Canadian regulatory agencies at federal and state or provincial levels of government have addressed mercury $(\mathrm{Hg})$ and deposition of this constituent as elemental or chemical compound [9]. In Europe the derivation of ecologically based CLs for certain metals (MCLs) is currently receiving increased attention $[10,11]$. In the US, metals criteria developed under the auspices of CAA and other regulatory programs such as Mercury and Air Toxic Standards (MATS; [9]) remain primarily concentration-driven or levied on numeric endpoints other than load or ecological effects. For example, ambient air values for $\mathrm{Pb}\left(0.15 \mu \mathrm{g} / \mathrm{m}^{3}\right.$; [6] $)$ or presumptive baseline values derived from monitoring activities for atmospheric $\mathrm{Hg}$ (1.4 to $1.6 \mathrm{ng} \mathrm{Hg} / \mathrm{m}^{3}$; [12])—do not provide effects-based CL estimates for ecological recaptors. However, these empirically based values serve as starting points for addressing ecological effects, particularly when viewed within the context of historic and ongoing monitoring programs in UK and Europe.

Increased awareness that regulatory air criteria in the US are strongly weighted toward human health-based effects has resulted in natural resource-based guidance values being developed primarily on the CL concept. Recent policy reviews by USEPA depended in large part from studies completed by the US Forest Service and the NPS, who are supporting research focused on air quality and atmospheric deposition issues that potentially affect ecosystems for which they are responsible [7]. In that 2010 assessment the USEPA broadly categorized effects related to acidification and nutrient-enrichment in terrestrial and aquatic ecosystems, but with emphasis on freshwater lakes and streams. Accordingly, that analysis relied heavily on aquatic indicators, including fishes, aquatic vegetation, and phytoplankton; however, effects on terrestrial vegetation (primarily vascular plants) was also addressed. Following historic precedent [13], USEPA reliance on growth-related measures and reproduction was reflected by their conclusion that the existing secondary standard for NOx did not protect certain ecosystems from impairment. As USEPA noted, most terrestrial ecosystems in the US are N-limited, and therefore, sensitive to perturbation caused by $\mathrm{N}$ additions. Importantly, under current conditions nearly all mixed conifer forests in the US receive total $\mathrm{N}$ deposition loads greater than $3.1 \mathrm{~kg} \mathrm{~N}$ $\mathrm{ha}^{-1} \cdot \mathrm{yr}^{-1}$ - a value suggested as an ecological benchmark associated with changes in lichen species composition and ultimately, broader terrestrial ecosystem changes [7, 14].

\section{Derivation of CL Models for Nitrogen and Metals}

Regardless of the atmospheric chemicals of concern, CLs for elemental or chemical constituents of ambient air may be calculated based on one of three general model systems - empirical, simple mass balance, or dynamic. Each is based to varying extents on observational studies or the compilation and assembly of existing data, with attempts to integrate results from both field and laboratory studies [15]. Derivation of empirical CLs is often undertaken when observational data are presumed as a response variable within an exposed system. For example, in terrestrial ecosystems the responses of vascular plants [16-18], cryptogams $[14,19]$ or soil physicochemical characteristics [10,20-22] have been correlated to elemental deposition that is spatiotemporally linked to the observed responses. In contrast, simple mass balance CLs are cal- 
culated values that are based on inputs and outputs of the chemicals (e.g., $\mathrm{N}$ as a nutrient) or physicochemical processes of soils (e.g., acid neutralizing capacity) that might be of particular concern to resource managers. Simple mass balance methods yield estimates of CLs based on underlying assumptions of steady-state conditions existing over relatively long periods of time. Dynamic models also employ a mass balance approach, but in addition they incorporate system feedbacks that yield time-sensitive estimates for CL. For example, accumulation of $\mathrm{N}$ as a nutrient within a system is considered relative to losses calculated from leaching, denitrification, and other processes.

Whereas empirical models or simple mass balance models are static unless updated and statistically considered as priors (e.g., in Bayesian applications) or as individual "snapshots" in a time-series analysis, dynamic models allow for forecasts of effects linked with exposure under a variety of resource management scenarios. Importantly, methods deployed to estimate CLs depend largely on the data available to modelers. For example, empirical CLs require observational data of known quality for both "exposure" (e.g., deposition values for chemicals of concern) and "effects" (e.g., spatially linked response data collected for vegetation during the period of deposition). In contrast, simple mass balance estimates of CLs depend instead on relatively long-term, intensive data sets to characterize exposure and effects presumptively linked to deposition through comparison of net gains and losses through time. Dynamic models apply similar spatiotemporal data to characterize exposure and effects, but require additional data to incorporate system feedback. Needless to say, dynamic models are generally the most data intensive, and ideally the supporting data have been carefully collected through field observational studies designed especially for long term assessment.

\subsection{Presumptive Critical Loads for Nitrogen as a Nutrient or a Toxin}

As noted by many authors [23,24], increased nitrogen deposition to terrestrial and freshwater ecosystems can lead to eutrophication or acidification. These processes can alter plant species communities through both toxicity to oligotrophic taxa and increased competition by more nitrogen-dependent taxa, depending in part on the sensitivity of vegetation to $\mathrm{N}$ loading and other environmental stresses $[25,26]$. European scientific communities have been active in developing habitat-specific, ecologically-focused CL benchmark values, and in developing predictive tools that characterize spatial and temporal forecasts for nitrogen deposition and CLs. Under the auspices of the United Nations, CLs for $\mathrm{N}$ based on detrimental effects on vegetation were first characterized under LRTAP in 1992, and were subsequently revised in 1996, 2002, and 2010. The most recent update initially focused on synthesizing existing data to better quantify inputs (loads) of atmospheric chemicals on both terrestrial and aquatic systems, then identified research needs to fill management-critical data gaps [27,28]. Various geographic information systems or statistical manipulations were applied to formulate spatiotemporal integrations of the existing empirical-load data. Table 1 compares CL estimates for nitrogen in boreal and arctic ecosystems of Europe (based on the aforementioned 2002 and 2010 reports), to that of North America, the latter which are based on synthesis by Pardo, Fenn, et al. [4]. Critical loads have been recommended for other habitats; however, our selections in Table 1 are limited to habitats comparable to those present in arctic, sub-arctic, and boreal regions of North America. Values in Table 1 are based on empirical data from field observations and from dosing experiments, yet considerable uncertainty remains, espe-

Table 1. Recommended critical loads of atmospheric nitrogen deposition for North American and European high-latitude habitats.

\begin{tabular}{|c|c|c|c|}
\hline \multirow{2}{*}{ Ecosystem type } & \multicolumn{2}{|c|}{ Nitrogen critical load ${ }^{*}\left(\mathrm{~kg} \mathrm{~N} \mathrm{ha}^{-1} \cdot \mathrm{yr}^{-1}\right)$} & \multirow{2}{*}{ Indication of exceedance } \\
\hline & 2002 estimates & 2010/2011 estimates & \\
\hline \multicolumn{4}{|c|}{ North America $[4,31]$} \\
\hline Tundra & -- & $1-3^{(\#)}$ & $\begin{array}{l}\text { Changes in lichen pigment production and ultrastructure, } \\
\text { changes in lichen and bryophyte cover }\end{array}$ \\
\hline \multirow[t]{2}{*}{ Taiga } & -- & $1-3^{\#}$ & $\begin{array}{l}\text { Changes in alga, bryophyte, and lichen community } \\
\text { composition, cover, tissue } \mathrm{N} \text { or growth rates }\end{array}$ \\
\hline & \multicolumn{2}{|r|}{ Europe $[28,32]$} & \\
\hline Tundra & $5-10^{\mathrm{a}, \#}$ & $3-5^{\mathrm{a}, \#}$ & $\begin{array}{l}\text { Changes in biomass, physiological effects, changes in } \\
\text { species composition in moss layer, decrease in lichens }\end{array}$ \\
\hline $\begin{array}{l}\text { Arctic, alpine and subalpine } \\
\text { scrub habitats }\end{array}$ & $10-15^{\mathrm{a},(\#)}$ & $5-15^{\mathrm{a}, \#}$ & Decline in lichens, mosses, and evergreen shrubs \\
\hline
\end{tabular}

*Reliability estimate; ${ }^{\#}$ fairly reliable, ${ }^{(\#)}$ expert judgment; ${ }^{a}$ apply high end of range, if phosphorus limited and lower end if phosphorus is not limiting. 
cially for Arctic regions of North America. Across high latitudes of Europe, as well as North America, nitrogen deposition currently ranges from $<2-20 \mathrm{~kg} \mathrm{~N} \mathrm{ha} \cdot \mathrm{yr}^{-1}$ in boreal and arctic ecosystems, depending on proximity to point source releases and prevailing winds (seasonal or annual). Importantly, high latitude tundra and taiga habitats of interior Alaska are considered to be among the most sensitive to nitrogen loadings because of potential disturbance to abundant lichen communities; yet for much of Alaska the scarcity of available loading data precludes the accurate determination of nitrogen CL exceedances for this region [4]. In any event, as modelers await the acquisition of additional physical data from case studies, the development of lichen-based critical loads for nitrogen, sulfur, and metals continues to be promoted for many ecoregions $[19,29,30]$.

Regardless of the depiction of critical loads as a numeric value or range of values, or as a mapping projected from a set of empirical critical load estimates derived from variously distributed spatial sample points, the presumptive critical loads developed for high latitudes of North America have limitations. For example, existing data are sufficient to develop estimates of critical loads, yet from a statistical perspective the data offerings remain relatively sparsely located in many areas. Although European insights provide presumptive benchmarks for critical loads for high latitude regions in general, such values may not be truly representative of arctic and boreal settings of North America. In addition, some manipulative studies captured in existing data compilations include CL values resulting from "high-dose" experiments that require extrapolation to effects from studies (hypothetical or actual) that consider relatively low nitrogen loads over relatively long time periods (e.g., $1-2 \mathrm{~kg} \mathrm{~N}$ $\mathrm{ha}^{-1} \cdot \mathrm{yr}^{-1}$ for 25 consecutive years). Recommended critical loads reliant predominately on the European experience also capture data from field observations and nitrogen addition experiments performed in areas previously exposed to relatively large atmospheric nitrogen inputs over decades of time. Consequently, impacts on vegetation communities might have already occurred in those studies due to increased nitrogen gained prior to observation [4]. The relative paucity low-dose field trials for nitrogen suggests that additional long-term field observations with controlled, low-dose exposure studies are needed to better quantify uncertainty within the context of adaptive resource management.

\subsection{Critical Loads for Metals-A Generalized Derivation Process}

In recent history CLs for nitrogen and sulfur focused on ecological effects linked to air quality, the former as a nutrient and along with sulfur as an atmospheric input affecting acidity of freshwater systems. More recently, potential effects from other constituents of atmospheric aerosols have gained increased interest from natural resource managers and regulators. Metals such as cadmium (Cd), lead, and mercury can be highly toxic to humans, but also can be phytotoxic or cause other ecological effects [33,34]. The need for MCLs became more widely emphasized in the 1990s when several investigators contributed to their development [26,35]. In Europe, analysis of spatial distributions of $\mathrm{Cd}, \mathrm{Pb}$, and $\mathrm{Hg}$ loadings allowed preliminary maps for MCLs to be constructed, including methods for their derivation [9-11,26,33,35]. Following those initial mapping efforts, the European MCLs have been refined through an iterative development process. Various related approaches to quantifying atmospheric deposition of metals have been applied, including preliminary characterization as concentration criteria or as CL values in the US [34] and in UK and Europe following technical guidance of UNECE $[3,5]$ or others $[10$, 26,35,36,38-41]. For example, De Vries et al. [37], among others, developed algorithms used in calculating MCLs with their initial efforts focused on characterizing critical loads for $\mathrm{Cd}, \mathrm{Pb}$ and $\mathrm{Hg}$ in forested ecosystems. Subsequent application of these algorithms in Europe has extended the tool's deployment to other metals and has served as extensions into dynamic models [42]. As currently deployed, algorithms yielding MCLs use a mass balance model keyed to metal fluxes in an ecosystem at steady state. In this case, metal concentrations in the system being modeled do not change through time and the net flux in the modeled system is zero. Depending on the time required for the system to reach a net flux of zero, the rate of change between system states reflects the difference between material gains and losses, which [35] originally was characterized as the difference between snapshots of current load and presumptive critical load.

Depending on the metal of concern, processes affecting its bioavailability in soil interstitial water might be incorporated into the derivation of the MCLs. Within the model framework, soil properties affecting transfer functions (e.g., soil-to-plant transfers) are largely based on laboratory studies focused on characterization of adsorption and desorption relationships between soil water and soil particles, which will depend largely on $\mathrm{pH}$ and soil geochemistry. Sorption by soil organic matter is a primary factor controlling the bioavailability of most metals, whereas $\mathrm{pH}$ tends to affect solubility in a more metalspecific manner [43]. For example, compared to most metals, $\mathrm{Pb}$ tends to be more strongly bound on soil particles both because of its lower water solubility at a given $\mathrm{pH}$ and because it has a strong affinity for metal-binding sites on humic substances. Furthermore, $\mathrm{pH}$ influences the rate of desorption of metal ions from soil particles, which at a given $\mathrm{pH}$ tends to be slower for $\mathrm{Pb}$ than co- 
occurring metals such as $\mathrm{Cd}$ or $\mathrm{Zn}$. And, compared to all other metals, $\mathrm{Hg}$ is in another class altogether. Its solubility, mobility, as well as microbial methylation in soils and sediments are strongly affected by the amount and type of organic matter - both in the solid phase (particles) of the soil or sediment and the dissolved phase of the surrounding water. Consequently, an MCL for $\mathrm{Hg}$ will depend on organic content of soils differently than one for $\mathrm{Cd}$ or $\mathrm{Pb}[44]$.

Certain system attributes such as weathering and other aging processes are more difficult to quantify in the current models for deriving MCL values. Inclusion of these processes as model input variables will require additional research, particularly as components that affect uncertainty. Surface runoff and erosion factors are also presently undervalued, largely because such processes contribute to spatially limited relocations of soils which cannot be captured by current mapping efforts, despite serving as important inputs to surface waters [44,45]. Overall then, derivation of MCLs differs from the more empirically dependent simple mass balance approaches used in the derivation of CLs for $\mathrm{N}$ as nutrient. Consequently, the development of a simple tabular summary of numeric MCL values is generally not feasible. As such, to keep the approach for characterizing MCLs consistent with the analogous process developed for $\mathrm{N}$ as nutrient, baseline characterization of metals cycling within an ecosystem is not quantitatively characterized. Hence, uncertainties related to transfer functions among various compartments within an ecosystem have to be considered within the construct of MCLs. In general, those can only be calculated from a system perspective focused on the sum of inputs and outputs and predicated on net metal uptake and metal leaching [11,33,35,42].

Given the spatiotemporal setting, a system's vulnerability and risks to atmospheric deposition of metals may be evaluated using the range of modeling tools discussed earlier. Depending on the models of choice, analytical outcomes may be interpreted by resource managers, e.g., as a snapshot of current status of the system or to forecast future states potentially linked to atmospheric deposition of metals. For example, if deposition currently exceeds an MCL, the receiving systems may already exhibit impacts linked to metal exposures, or if soils present initial conditions characterized by reduced organic content, the system might be more vulnerable to metal loads from air sources deposited in the future under a range of management scenarios. Deposition rates and associated biological responses may differ among metals and soils from one area within the landscape to another (e.g., air shed or catchments); hence, forecasts of future states are highly dependent on past data collections for the receiving system (e.g., soil and vegetation records) and ongoing monitoring activities.

\subsection{Mapping Metals CLs for Arctic and Boreal Habitats}

As were CLs for N as a nutrient, derivation of MCLs has been considered categorically by "ecosystem types" and "EUNIS code" [39]. For selected metals ( $\mathrm{Pb}, \mathrm{Cd}$, or $\mathrm{Hg}$ ), numeric values for these benchmarks reflect input metal flux for a defined area and depth of soil that does not exceed a specified effects-based limit when the system is at steady-state (no net accumulation or loss of metal in a defined soil volume). For example, within a given EUNIS code an MCL for $\mathrm{Pb}, \mathrm{Cd}$, or $\mathrm{Hg}$ would reflect a receptor-specific load predicated on the threshold below which significant effects on the receptor are assumed not to occur. Specific MCLs might vary within each EUNIS code by individual receptor species, groups of species, or the terrestrial ecosystem as a whole. Because of these complexities, modeling is essential for integrating processes that govern the fate and bioavailability of metals for specific receptors of such higher-order ecosystems. For derivation of MCLs and mapping of a current status, models are typically based first on $\mathrm{pH}$-dependent free metal ion activities, properties of substrates (e.g., soil pH and organic content), and landscape attributes (e.g., slope) which account for variation in soil vulnerabilities across a given habitat or area of concern (e.g., EUNIS code). By characterizing the receiving areas and accounting for spatiotemporal variations in soil properties, the MCLs and areas of exceedances were mapped for the UK and Europe [11,36,37]. These maps were updated most recently in 2008 and were based on 2006 data (Figure 2) [41]. In addition, updates reflecting alternative management-driven scenarios incorporated into the analysis have been suggested $[41,45]$. Similarly, ongoing work by participating member nations in the LRTAP program has led to the development of MCLs for $\mathrm{Cd}, \mathrm{Pb}$, and $\mathrm{Hg}$, for specific ecosystem categories as well as providing empirical data supporting models currently in place to derive these benchmark values. For example, MCLs for $\mathrm{Cd}, \mathrm{Pb}$, and $\mathrm{Hg}$ in selected Swedish soils were estimated in a demonstration of process (Table 2; [5]). Given the observed influence that the occurrence of humic materials played in offsetting adverse effects linked to $\mathrm{Pb}$ inputs, such work contributes to our understanding of how soil properties such as $\mathrm{pH}$ and organic content affect MCLs that potentially serve as benchmarks for forecasting exceedances. In Canada, more regionally driven metal deposition maps have been presented that are focused on $\mathrm{Cd}$ and $\mathrm{Pb}$, as well as copper, nickel, zinc, and arsenic resulting from metal production facilities [46].

For arctic habitats, vegetation indicators other than vascular plants typically employed at mid-latitude (e.g., agronomic crops and forests) may be critical to developing relevant adaptive management plans. Here, ecosystems at 


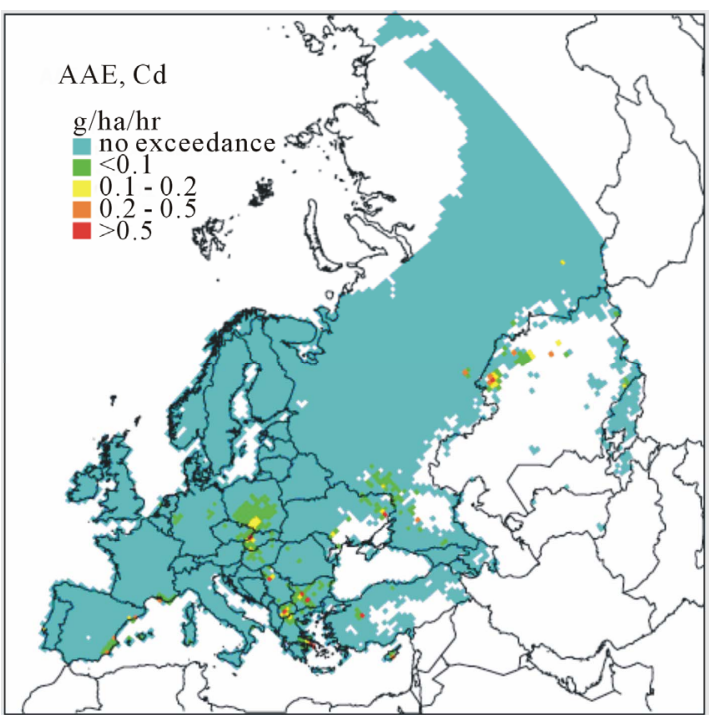

(a)

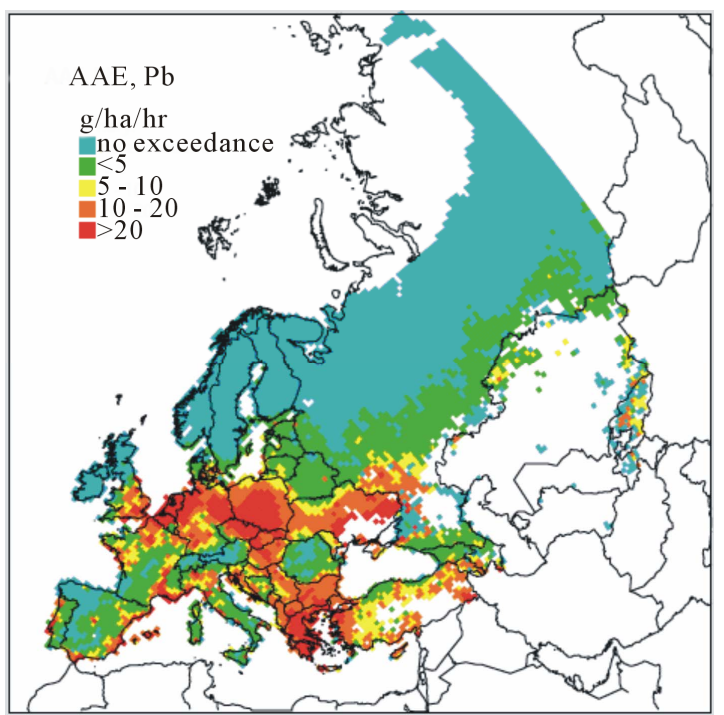

(b)

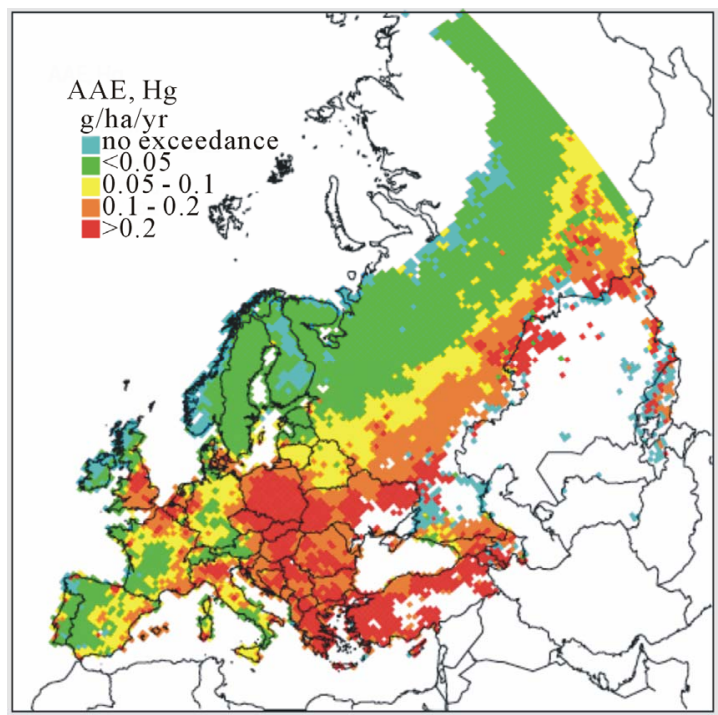

(c)

Figure 2. Accumulative Annual Exceedance (AAE) forecast maps for (a) Cd, (b) Pb, and (c) Hg based on conditions characterized in 2006 [41].

Table 2. Example of MCLs developed for selected soils in Sweden [5].

\begin{tabular}{cccc}
\hline Location Identity, Soil layer & $\mathbf{P b}\left(\mathbf{m g} / \mathbf{m}^{2} / \mathbf{y r}\right)$ & $\mathbf{C d}\left(\mathbf{m g} / \mathbf{m}^{2} / \mathbf{y r}\right)$ & $\mathbf{H g}\left(\mathbf{m g} / \mathbf{m}^{2} / \mathbf{y r}\right)$ \\
\hline Sweden 14, humus layer & 5.0 & 0.8 & 0.016 \\
Sweden 14, E-horizon & 1.6 & 0.6 & 0.006 \\
Sweden 15, humus layer & 4.0 & 1.0 & 0.013 \\
Sweden 15, E-horizon & 2.0 & 0.9 & 1.4 \\
Sweden 16, humus layer & 8.0 & 1.0 & 0 \\
Sweden 16, E-horizon & 1.0 & & \\
\hline
\end{tabular}

risk could benefit from the experience gained in atmospheric monitoring for metals using cryptogams such as mosses and lichens; however, as indicated previously, soil properties may be of little consequence for these re- 
ceptors in habitats of interior Alaska. Yet, models for MCLs which are based solely on certain lichen community responses seem to be lacking. Most studies documenting lichen community effects from metal sources have focused on areas near smelters, or urban and industrial regions, where typically there also are large SOx emissions [46]. Because many lichen species are quite sensitive to SOx exposure [47], and because typically a suite of metals may be present in emissions or fugitive dusts, it may be difficult to determine which stressor is most responsible for damage. Accordingly, Conti and Cecchetti [47] noted that precautions are necessary when attempting to use lichens as a quantitative measure of effects from a single contaminant because they do not necessarily exhibit unique responses to specific contaminants. Regardless, revisions to MCLs that are based on metal-sensitive lichen community responses could be an important area of study, especially for Arctic Alaska. As was previously noted for nitrogen, historic metal loadings across much of Europe might have impacted vegetation communities long before CL studies began there; consequently, MCLs derived for European habitats might be biased high when applied to Arctic Alaska. Despite potential differences between ecosystems and historic inputs, the recently updated European MCLs [45] values for $\mathrm{Cd}, \mathrm{Pb}$, and $\mathrm{Hg}$ might be adopted preliminarily by Alaska resource managers, at least within the context of methods development and monitoring framework(s) of ongoing studies.

\section{Mosses as Biomonitors of Nitrogen, Sulfur, and Metals}

Cryptogams such as mosses and lichens easily fit the role of biota representative of these high latitude biomes, and species that are nearly cosmopolitan in distribution are key components in long-term monitoring activities envisioned for Arctic Network of the National Park Service. Their increased role as biomonitors comes about primarily because costs associated with their collection and analysis are low compared to alternatives such as instrumental monitors and passive abiotic samplers. Use of mosses to assess atmospheric deposition of chemicals in northern Europe began in the late 1960s and early 1970s, $[48,49]$ and they have been used to monitor and map deposition of atmospheric chemicals over the past 30 years $[48,50]$. Use of lichens as biomonitors also has been widely reported [47,51-53], but compared to mosses their use by NPS in Arctic Alaska is less common. This is due in part because it is more difficult to obtain a suitable sample mass of terrestrial lichens for analysis (unlike epiphytes), but also because certain mosses are more pollution tolerant and widespread, and seem to be more amenable to "calibration" to deposition or loading [54].
Despite some limitations, mosses and lichens continue to serve as robust indicators of exposure for a range of powerful biological monitoring tools $[53,55]$. Such activity has been underwritten by life history attributes unique to these cryptogams, particularly their dependence on nutrients and accumulation of chemicals almost exclusively from atmosphere. Mosses lack a root system and do not present a prominent cuticle, which could otherwise strongly affect the sources and transport vectors contributing to chemical uptake [56,57]. Also, cation exchange capacity in mosses is relatively high, and across the range of bryophytes, all species of moss present a high surface areato-volume ratio which likely maximizes accumulation of nutrients and other environmental chemicals via these pathways.

Mosses have found widespread use for monitoring purposes, but debate continues regarding how concentrations in moss can be interpreted and compared to bulk and/or wet deposition sampling methods [58,59]. For one, their accuracy as monitors will become reduced once exposure levels are high enough to impair metabolism [54]. Secondly, several localized factors, both biotic and abiotic, have been identified as potentially problematic, particularly when applying moss monitoring data across regional scales [54,58,60-62]. For example, identification of sources and interpretation of concentrations accumulated by mosses, as well as alternative monitoring methods, can be complicated by the fact that volatility of individual metals and the type of source(s) are likely to limit the effective range of atmospheric transport [61,63]. Furthermore, a number of abiotic factors may modify uptake of metals and other pollutants by mosses. These include: influences from windblown soil dust or particulates, dry deposition (including aerosols and fine particulates) originating from local pollutant sources; decreased uptake rates in coastal regions as affected by competitive ion-exchange by $\mathrm{Na}$ and $\mathrm{Mg}$ in marine aerosols; influence of precipitation intensity, duration and frequency; and finally, the substrate and altitude where the moss is sampled. Notably, mosses may accumulate considerable quantities of fine particulates on their surfaces. Therefore, depending on the goals of the monitoring effort, the removal of surficial particulates by washing samples before analysis might be preferable [60]; however, washing is typically not done according to most monitoring program protocols. Biotic factors including moss species, age, growth rate, tissue parts sampled, and abundance of nearby vegetation may also affect interpretation; however, many of these factors might be important only when low concentrations are involved [55]. Complicating factors unique to arctic regions potentially include contributions from surface water flow during snowmelt, greater susceptibility to soil particle influences associated with wind 
erosion, and slow growth rates [64]. The first two problems can largely be circumvented by choosing moss species and sampling locations carefully so as to avoid topographical depressions, areas of sparse underlying peat substrate, and eroded or otherwise disturbed soil habitats [65]. Fortunately, certain feather mosses, including $\mathrm{Hy}$ locomium splendens, typically grow only on beds of humic-rich peat surfaces which should minimize potential transfer of most metal ions from underlying soils as well as during water transport during snowmelt. Slower growth rates could be problematic when comparing between arctic and sub-arctic regions because although annular growth segments can be readily distinguished in many mosses including Hylocomium splendens, slower growth rates in polar regions might translate to greater metal uptake per unit weight as compared with more temperate climates [64]. Regardless, because of these uncertainties, some researchers have concluded that continued research is needed to better characterize the relationships between metal residues and exposure pathways so as to improve interpretation of moss metal-residue data as an alternative to quantification of atmospheric deposition [58]. As such, continued work focused on mechanisms underlying the physicochemical and biological conditions could better characterize the foundation for the role that mosses play in biological monitoring for atmospheric deposition of metals, as well as any associated critical loads.

Past reviews on the use of mosses for monitoring atmospheric pollutants generally agree that mosses are useful for monitoring deposition of nitrogen and certain heavy metals [50,66-68], but perhaps less so for sulfur species in part because many species of mosses, and especially lichens, are relatively sensitive to exposure to gaseous sulfur dioxide and sulfuric acid [51,54,55,61,67, 69,70]. Many studies involving metals, particularly $\mathrm{Cd}$ and $\mathrm{Pb}$, and to a lesser extent, $\mathrm{Hg}$, have observed relatively well defined relationships between metal deposition and metal accumulation in mosses and/or with increasing distance from presumed atmospheric sources [50,66,71-73]. Lead, in particular, is known to be strongly accumulated and retained by mosses [71]. Based on a series of independent studies, the efficiency of metal uptake by mosses from metal ions in wet deposition has been estimated as: As, 25\%; Cu, 35\%; Ni, 50\%; $\mathrm{Cd} / \mathrm{Co} /$ $\mathrm{Mo} / \mathrm{V} / \mathrm{Zn}, 60 \%$; Cr, 65\%; Fe, 70\%; and $\mathrm{Pb} / \mathrm{Tl}, 100 \%$ [54].

In what is probably the most widely cited paper on the topic, accumulation of several metals by mosses was shown to exhibit well-defined linear relationships with bulk deposition measurements within Scandinavia, but only if a small number of outlier sites located near smelters or other strong point sources were excluded in the data regressions [71]. Such results bring into question once again the debate concerning the interpretation of moss data, particularly in the context of wet $v$. dry deposition, as well as the likelihood that accumulation rates may differ depending upon the source(s) - be it wet precipitation, urban air pollution, industry, power plant or smelter emission, or fugitive dust from mining operations $[58,62]$. In one laboratory study with the moss (Scleropodium purum), considerable levels of metals were found to be accumulated via exposure to dry deposition as compared with wet deposition [74]. Those same authors concluded that extrapolation of calibrations between the concentrations of elements within individual species of moss to values of atmospheric bulk deposition from one place to another having different environmental conditions (i.e., watershed variability) might not be valid. If not, then models which relate moss concentrations to that of concentrations in deposition that are based on studies conducted in northern Europe might not be applicable to comparable arctic habitats of North America. Based on a comparison of early 1990s moss concentrations and variability for five metals among 24 sites spanning Arctic Alaska to that of moss data from countries of northern Europe, it was concluded that direct comparisons might be valid for $\mathrm{Cu}, \mathrm{Pb}$, and $\mathrm{V}$, but not for $\mathrm{Cd}$ and $\mathrm{Zn}$, because of high inter-watershed variability for the latter two metals [65]. Regardless, what is apparent from these and other studies is the fact that dry deposition is an important route of exposure and uptake of metals by mosses; therefore, it follows that critical loads for metals should not be derived solely by measurements obtained in wet deposition. Secondly, despite concerns about data interpretation and applicability, use of moss for monitoring is widely regarded as a highly successful endeavor and has encouraged the development of presumptive MCLs for metals $[39,50,71,75,76]$.

\section{Vulnerabilities and Risks Associated with Increasing Nitrogen Loads in Interior Alaska}

With respect to $\mathrm{N}$ loads, the availability of nutrients is a critical abiotic factor affecting vascular and non-vascular plant species. Nitrogen is the limiting nutrient for plant growth, especially in oligotrophic and mesotrophic surface waters or terrestrial habitats that are depleted in $\mathrm{N}$ stores [77]. In these relatively nutrient-deficient habitats, cryptogams such as mosses and lichens are singly dependent on atmospheric inputs [78]. From a biogeochemical perspective, the nitrogen cycle is relatively complex and involves a highly regulated network of biological and microbiological processes set on a stage of physical habitat that provides inorganic and organic inputs of $\mathrm{N}$ in the cycling process (Figure 3). Indeed, $\mathrm{N}$ cycling reflects differential inputs from naturally-occurring pro- 
cesses supplemented by anthropogenic sources, and changes in plant responses will reflect species-specific attributes and soil-based processes that are interrelated, but differentially reflected in the increased deposition of air-borne $\mathrm{N}$.

Nitrogen may largely be retained within a system as biomass with little being leached from the soil. Denitrification generally occurs at a low rate and tends to be nutrient limited. Because the rate of fixation depends on temperature and moisture, it varies throughout the year. Although metabolism of nitrogen is temperature dependent, it is not dramatically inhibited by low soil temperatures typical of the Arctic. Indeed, nitrogen cycling, including fixation in arctic habitats has been studied in bacteria, soil algae, lichens and legumes, with soil cyanobacteria being a key free-living species in association with mosses, or as phycobionts in lichens [80-83].

A simple observation of effects of $\mathrm{N}$ loads must be considered within the context of highly adaptive, highly complex systems that interact and operate at different temporal and spatial scales. For example, in high latitude areas of northern Europe, sensitivity to atmospheric nitrogen deposition is highly variable among and within natural and semi-natural ecosystems. Habitats that historically presented low nutrient status and relatively low deposition rates are often most vulnerable to disruption. Typically, such ecosystems have relatively little buffering capacity to offset what elsewhere might be minor increases in $\mathrm{N}$ loads. In these systems, increased $\mathrm{N}$ deposition can result in significant changes in vegetation composition and diversity and in nitrogen cycling. In particular, relatively low, N-limited terrestrial systems such as grasslands, deserts, and arctic, alpine, and health and habitats are susceptible to vegetation community alteration resulting from small increases in $\mathrm{N}$ availability [18,28, 84]. For these habitats, bryophytes, oligotrophic lichens, insectivorous plants, and other vegetation reliant on symbiotic relationships with $\mathrm{N}$-fixing bacteria or mycorrhizal

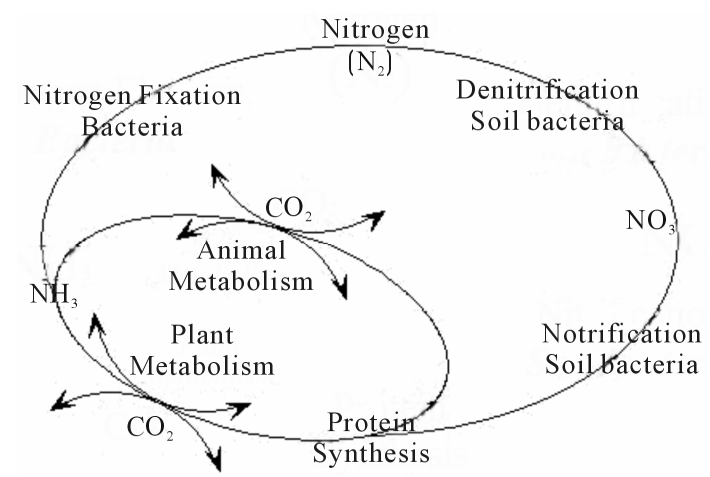

Figure 3. Coarse-grained sketch of biogeochemical cycle for nitrogen that can be subsequently decomposed to finegrained conceptual models focused on specific components [79]. fungi tend to lose their competitive advantage over other plant types when nitrogen loadings increase in an otherwise N-limited ecosystem [27,28,31].

The existing literature amply underscores that arctic ecosystems tend to be nutrient limited and are highly sensitive to nutrient enrichment, particularly by nitrogen and phosphorus [85]. Indeed, at the close of the $20^{\text {th }}$ century in Europe, CL values for nitrogen for arctic heath habitats were estimated to be within the range of $10-15$ $\mathrm{kg} \mathrm{N} \mathrm{ha}{ }^{-1} \cdot \mathrm{yr}^{-1}$, which was advanced as an initial threshold effects level updated from early estimates [86], and more recently by accounting for nutrient interactions and effects on bryophytes $[84,87]$. Inputs of nitrogen to the Arctic have increased over the recent past and although inputs generally remain below critical load estimates, they are sufficient to characterize these habitats as vulnerable to nutrient loading $[4,88,89]$. And, given observations that summer surface temperatures at high latitudes have increased markedly over the last 30 years [90], increasing nitrogen inputs could have more dramatic effects in view of the potential impacts of climate change on the Arctic [91-94]. Furthermore, mineralization rates are likely to increase as soils warm, and nitrogen and phosphorus availability to the vegetation will likely increase [95-98]. Under current conditions, atmospheric deposition of nitrogen in the Arctic is generally quite low $\left(<1 \mathrm{~kg} \mathrm{~N} \mathrm{ha}{ }^{-1} \cdot \mathrm{yr}^{-1}\right)$; however, 1990s data indicate that some areas such as the Taymyr Peninsular in Russia and parts of extreme northern Alaska may exceed $10 \mathrm{~kg} \mathrm{~N}$ $\mathrm{ha}^{-1} \cdot \mathrm{yr}^{-1}$ [99-101]. Synthesis reports of the mid-1990s seem to have undervalued the role that increased atmospheric nitrogen deposition might contribute to altered vegetation signatures in the Arctic [102]. Subsequent studies in which increased nitrogen and phosphorus availability were experimentally manipulated at rates likely to occur via environmentally relevant atmospheric routes have identified effects in soils that included reduced mycorrhizal colonization of arctic shrubs and decreased fungal diversity [101]. An improved understanding of interrelationships between physical habitat and biological or ecological receptors in arctic and boreal regions of North America will be a key toward development of future adaptive management strategies as climate change shifts baselines.

Interior Alaska is a landscape characterized by a continental climate having a relatively wide range of temperatures between summer and winter with equally variable precipitation fluctuations about seasonal and annual means. Annual precipitation in interior Alaska is low and decreases from west to east, and over the past 50 years drought has become a critical force in a changing system [103]. Entanglements inevitably linked to differences in seasonal precipitation are captured by seasonal patterns in wet deposition of nitrogen. An integrated spatiotempo- 
ral snapshot of precipitation and wet deposition of nitrogen might lead scientists to surmise that biological and ecological receptors may adjust to offset outcomes of a simple climate-change scenario focused on temperature. For instance, if vegetation biomass increases sufficiently in response to increasing temperatures observed in interior Alaska, then shifts in $\mathrm{N}$ loading may not produce surprising changes in vegetation-vascular flowering plants or cryptogams. However, as a complex-adaptive system, arctic and boreal habitats of high latitudes in North America are likely to defy simple cause-effect models [104]. As suggested by a cursory review of existing literature focused on climate change, particularly, trends of increasing temperature (Figures 4(a) and (b)), altered linkages may develop between biogeochemical cycles of nitrogen and carbon, and changing precipitation regimes (Figures 4(c) and (d)) for interior Alaska [28,92,97,98, 105,106]. The role of permafrost soils as integral components of carbon and nitrogen cycles may become increasingly dynamic as both a sink and source of nitrogen, which will unavoidably affect the role of exogenous inputs of nitrogen and influence the characterization of critical loads for wet deposition. Soils characterized by continuous or discontinuous permafrost presumably will display different response signatures to $\mathrm{N}$ inputs. Indeed, uncertainties related to climate change and CLs for $\mathrm{N}$ dominate the current snapshot of a dynamic ecosystem that

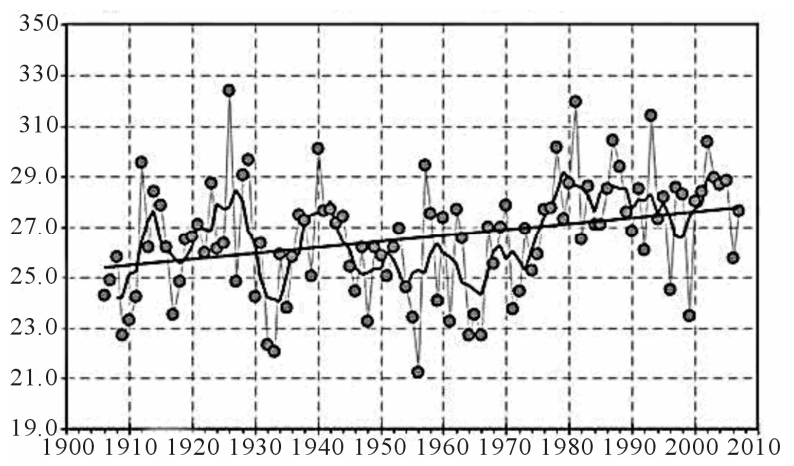

(a)

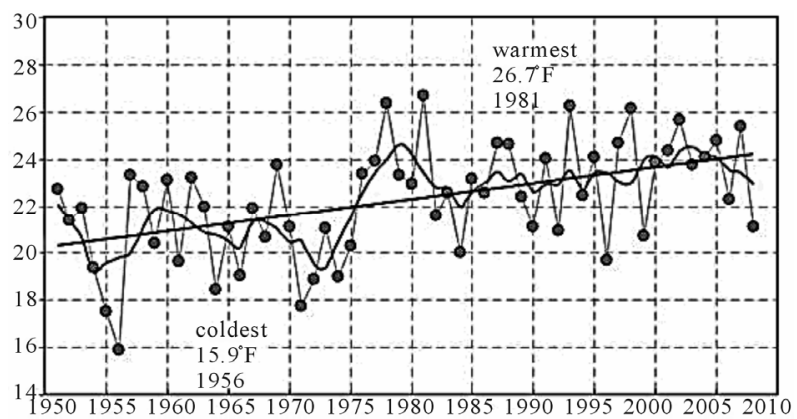

(c) may exhibit a relatively rapidly shifting baseline with respect to vegetation. And, climatic changes may inevitably be linked to biological and ecological impacts from nitrogen deposition even under scenarios of unchanged loads.

\section{Moss and Lichen Communities as Indicators of Ecosystem Responses to Nitrogen Loading in Multiple Stressor Exposures}

Despite substantial research focused on the role of cryptogams in arctic and in boreal habitats [83,107-110], existing literature sheds incomplete insight regarding the differential responses of mosses and lichens when exposed under multiple stressor scenarios. From an exposure perspective, cryptogams are uniquely adapted to being strongly linked to atmospheric sources of nutrients such as nitrogen and phosphorus. Because both are limiting factors in most arctic systems, increasing either will have an effect on the ecosystem. Given the physiological processes of lichens and mosses, and their prevalence of most arctic habitats, changes linked to increased nutrients and climate-change induced increases in, e.g., mineralization will likely yield shifts in the community structure of arctic ecosystems [84,111-113]. But, predicting these responses will not be straightforward, and will require filling data gaps, some of which may be management-

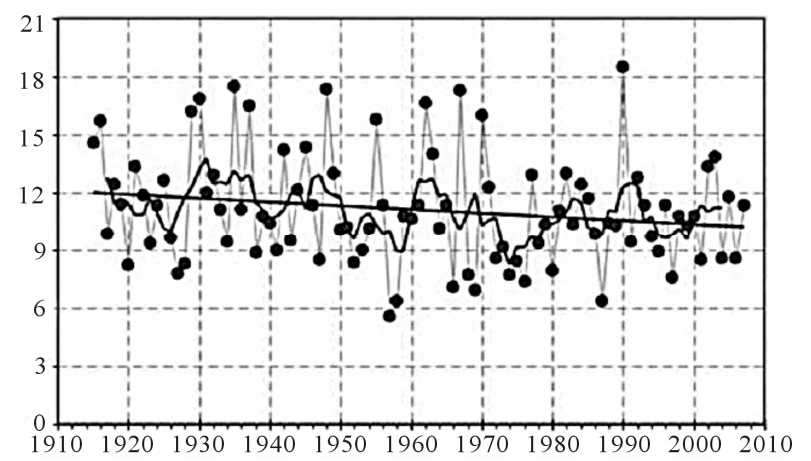

(b)

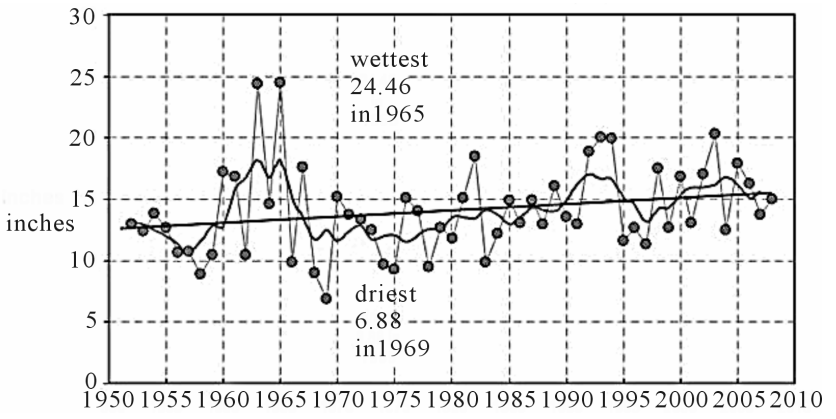

(d)

Figure 4. Mean annual temperature (a) and precipitation (b) trends at Fairbanks, Alaska. Data source:

http://climate.gi.alaska.edu/Climate/Location/TimeSeries/index.html; Mean annual temperature (c) and precipitation (d) trends at Bettles, Alaska. Data source: http://climate.gi.alaska.edu/Climate/Location/TimeSeries/index.html. 
critical.

For high latitude venues such as arctic and boreal terrestrial ecosystems, observational or experimental studies and synthesis works indicate that increased $\mathrm{N}$ accumulation contributes to, and is often a critical factor linked to changes to species composition $[28,84,91,98]$. Direct toxicity of nitrogen gasses and aerosols and long-term negative effects of increased ammonium and ammonia availability are also noted, particularly in combination with other components of atmospheric aerosols such as SOx, whereby $\mathrm{N}$ deposition contributes to soil-mediated effects of acidification [28,114-116]. Overall, the amount of annual $\mathrm{N}$ input through atmospheric deposition directly influences ecosystem functioning regardless of our focus, be it industrial and agricultural regions of the world $[28,117]$ or remote regions such as arctic and boreal habitats. Arctic (and alpine) communities are sensitive to increased atmospheric nitrogen input because within-system nitrogen retention is very efficient and regulated via a network of temperature- and moisture-dependent processes. In nutrient-poor systems such as arctic, boreal, and other such habitats (e.g., heathlands, bogs and fens of Europe), increased nitrogen deposition has contributed to enhanced primary production with shifts in the dominance of plant species, often associated with loss of plant diversity $[28,114,115,118,119]$. In boreal forests, increased nitrogen deposition has been linked to changes in plant tissue chemistry and soil nitrogen cycling, and ultimately, plant community composition [22]. In bogs and poor fens, exceedance of critical nitrogen loads reportedly yielded an initial increase, followed by a decrease Sphagnum spp. growth, which was linked to increased abundances of sedges, forbs, and selected ericaceous shrubs [120]. In those studies, nitrogen additions as low as $5 \mathrm{~kg} \mathrm{~N} \mathrm{ha}{ }^{-1} \cdot \mathrm{yr}^{-1}$ yielded floristic changes, and higher nitrogen deposition rates were associated with increased nitrogen concentrations in plant tissue which may inhibit plant growth $[22,120]$. Others have suggested that increased deposition rates and increases in plant tissue nitrogen may be linked to increased incidence of plant pathogens [121]. Such plant- and community-level changes inevitably will affect the structure and function of these arctic and boreal systems in the future. Within a multiple stressor context, increased eutrophication could act antagonistically when combined with additional stressors, including metals and other atmospherically derived pollutants.

\section{Preliminary Characterization of Nitrogen Load Estimates in Interior Alaska}

Regionally, the high latitudes of Alaska and Canada present a model of future alternatives framed against a backdrop of climate change. For example, development of the oil sands in Alberta has increased regional nitrogen emission rates, increasing inputs to high-latitude habitats from sources east of Alaska and western Canada; hence, increasing risks for eutrophication of arctic and boreal forest habitats and understory plant communities. As previously indicated, in the US critical loads are characterized periodically for regulated constituents [7], but presently have little regulatory bearing for ecological concerns. Derivation of more accurate $\mathrm{CL}$ estimates and development of CL maps specifically for interior Alaska will depend in part upon increased monitoring efforts. Such efforts might include abiotic passive sampling techniques [122, 123] or additional instrumental monitoring stations to complement measurements obtained by moss biomonitors. Currently, a National Trends Network (NTN) of ambient air monitoring stations provides annual snapshots of loadings from wet deposition for nitrogen (as ammonium and nitrate ions) and sulfur (as sulfate ion) [12]. In addition, select other constituents are measured as part of other nationally administered atmospheric monitoring networks; however, Alaska is represented by relatively few stations (Table 3; Figure 5). Nitrogen loads measured as ammonium, nitrate, or inorganic nitrogen in wet deposition have been relatively low at NADP/NTN monitoring stations of interior Alaska, except for a small number of outlier values (Figure 6). With the exception of the outliers, these levels are consistent with much of the European and North American literature regarding nitrogen loads for relatively undisturbed habitats at high latitudes. Yet, within the context of adaptive resource management and alternative futures, characterization of nitrogen loads in interior Alaska must consider changes in exposure to atmospheric deposition, and the interrelationships among sources, receiving systems, and their linking pathways. Indeed, changes in responses of these dynamic and adaptive systems may be associated with marked and rapid departures in responses to exposure as deposition patterns change. Although more complex statistical tools will be needed for future studies, our reconnaissance opted for tools of exploratory data analysis. For example, Figure 7 presents box plots of $\mathrm{N}$ deposition at the Bettles, Poker Creek, and Denali NADP/NTN stations to illustrate seasonal patterns of wet deposition, with data at the Denali station having been collected over the past 30 years.

As these data indicate, annual values for nitrogen load for NADP/NTN sites in Alaska are relatively low, yet within an ecological context, a multiple stressors analysis - one that includes dynamic states of physical habitat linked to climate change-should be folded into forecasts of alternative futures potentially critical to developing adaptive management plans for NPS parklands. Indeed, the evaluation of system vulnerabilities affords resource management agencies the opportunity to anticipate changes in physical and biological components of habitat that inevitably occur in any system exposed to perturbations that vary through time and space. For example, in annual 


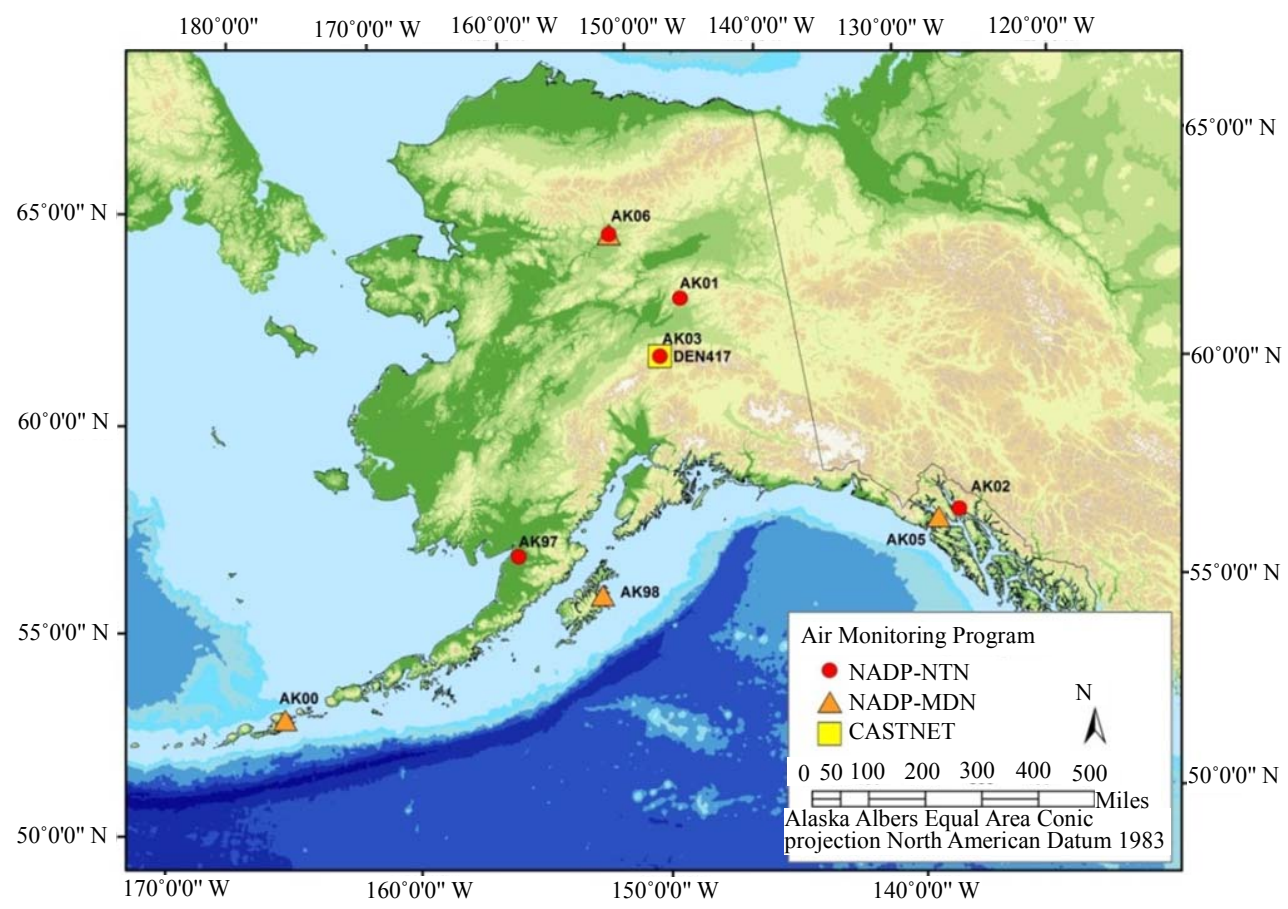

Figure 5. Locations of active air monitoring stations in Alaska (see Table 3 for details).

Table 3. Active (2013) atmospheric monitoring stations in Alaska.

\begin{tabular}{|c|c|c|c|c|c|c|c|c|}
\hline Program & Sample type & Focus & Station ID & $\begin{array}{l}\text { Location } \\
\text { description }\end{array}$ & $\begin{array}{l}\text { Operating } \\
\text { agency }\end{array}$ & Lat & Long & Start date \\
\hline \multirow[t]{5}{*}{ NADP-NTN } & wet deposition & $\mathrm{pH}$, conductance, & AK01 & Poker Creek & UA-F & 65.155 & -147.491 & Dec-92 \\
\hline & & $\mathrm{NH}_{4}^{+}, \mathrm{Ca}^{2+}, \mathrm{Mg}^{2+}$, & AK02 & Juneau & USFS & 58.514 & -134.784 & Jun-04 \\
\hline & & $\begin{array}{c}\mathrm{Na}^{+} \\
\mathrm{K}^{+}, \mathrm{Cl}^{-}\end{array}$ & AK03 & Denali NP & NPS & 63.723 & -148.968 & Jun-80 \\
\hline & & $\mathrm{NO}_{3}^{-}$ & AK06 & Bettles-GAAR & NPS & 66.906 & -151.683 & Nov-08 \\
\hline & & $\mathrm{SO}_{4}^{-}$ & AK97 & Katmai NP & NPS & 58.679 & -156.666 & Nov-09 \\
\hline \multicolumn{9}{|c|}{ source—http://nadp.sws.uiuc.edu/ntn/ } \\
\hline \multirow[t]{4}{*}{ NADP-MDN } & wet deposition & mercury & AK00 & Dutch Harbor & Alaska DEC & 53.845 & -166.505 & Sep-09 \\
\hline & & & AK05 & Glacier Bay NP & NPS & 58.457 & -135.867 & Mar-10 \\
\hline & & & AK06 & Bettles-GAAR & NPS & 66.906 & -151.683 & Nov-08 \\
\hline & & & AK98 & Kodiak & Alaska DEC & 57.719 & -152.562 & Sep-07 \\
\hline \multicolumn{9}{|c|}{ source—http://nadp.sws.uiuc.edu/mdn/ } \\
\hline $\begin{array}{l}\text { CASTNET } \\
\text { (USEPA) }\end{array}$ & $\begin{array}{c}\text { dry deposition } \\
\text { (gas/aerosol \& } \\
\text { particulate) }\end{array}$ & $\begin{array}{c}\mathrm{O}_{3} \text { (ozone), } \mathrm{HNO}_{3}, \\
\mathrm{SO}_{2}, \text { particulate } \\
\mathrm{NH}^{+}, \mathrm{NO}_{3}^{-}, \mathrm{SO}^{2-}\end{array}$ & DEN417 & Denali NP & NPS & 63.726 & -148.963 & Jan-98 \\
\hline
\end{tabular}

source-http://epa.gov/castnet/

NADP added monitoring programs for gaseous mercury (AmNet), and ammonia (Amon), but as of March 2013 there were no stations in Alaska.

Dry deposition/loads are estimated using continuous or discrete volume air sampling, meteorological data, and deposition models. 


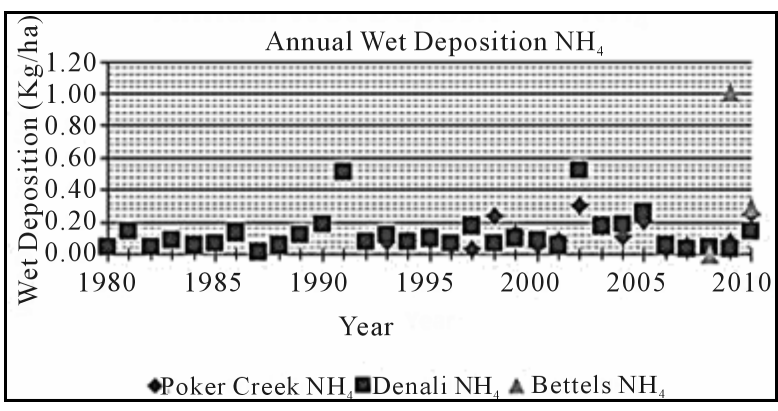

(a)

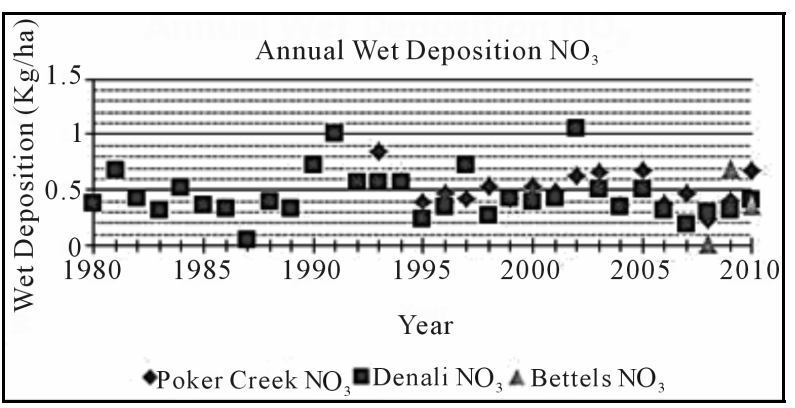

(b)

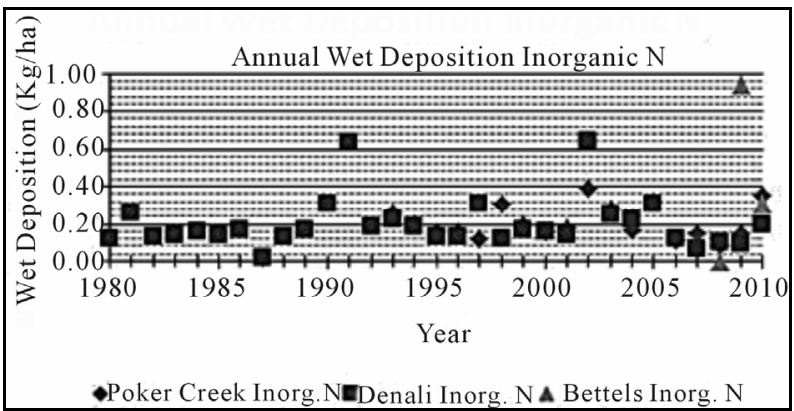

(C)

Figure 6. Annual wet deposition of nitrogen (as $\mathrm{NH}_{4}, \mathrm{NO}_{3}$, and inorganic $\mathrm{N}$ ) at NADP/NTN monitoring locations in interior Alaska (see Figure 5). Source: http://nadp.sws.uiuc.edu.

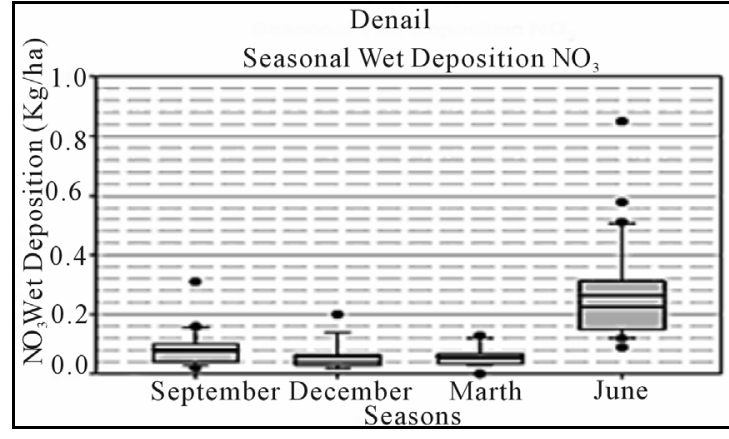

(a)

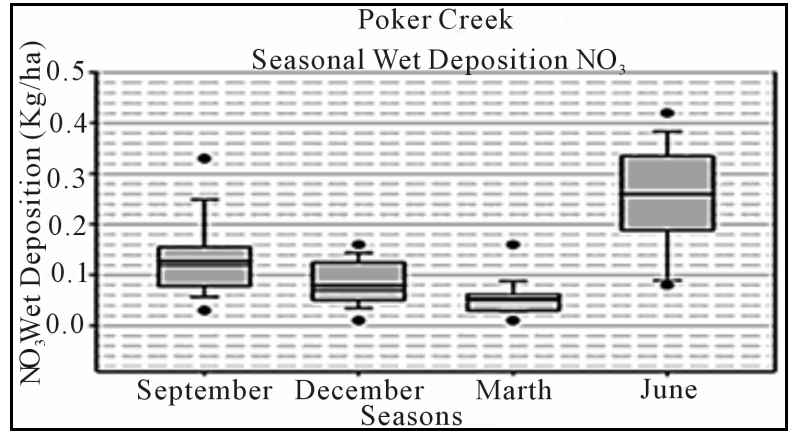

(b)

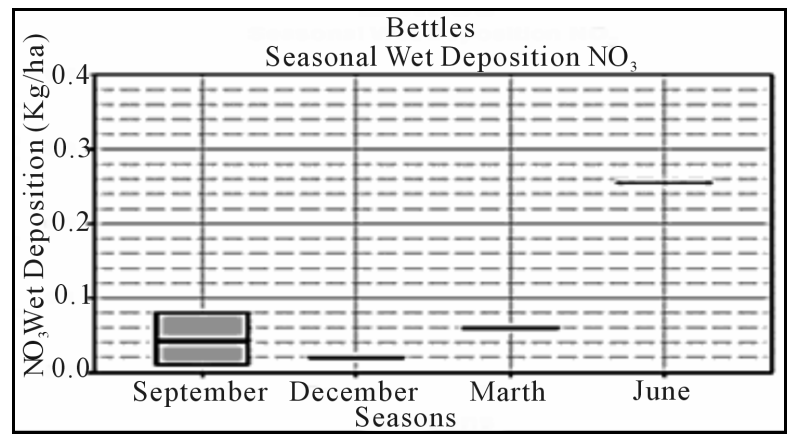

(c)

Figure 7. Simple box plots of seasonal $\mathrm{NO}_{3}$ wet deposition data collected from NADP/NTN monitoring locations in interior Alaska (see Figure 5). Source: http://nadp.sws.uiuc.edu.

snapshots summarized here, temporal components of risks, namely the influence of meterological conditions, e.g, winds and other seasonal factors influencing deposition, may be obscured. A better understanding of causal factors which contribute to the relatively high variability of loads observed during May, June, and July (Figure 7) 
could improve risk characterization analysis during specific months of the year. Similarly, for an evaluation of risks associated with atmospheric chemicals, be those exposures to ambient air or to dry-wet deposition, dispersal patterns in relation to prevailing winds must be adequately considered from both empirical data collection and a modeling perspective [124,125]. A system-level perspective based on seasonal loads might better inform adaptive management plans, and in the process be more responsive to multiple stressor inputs affecting the habitats at risk in near or distant futures. Under conditions currently observed and in the recent past, one might surmise or hind-cast how wet deposition of nitrogen may have been influenced by environmental inputs such as seasonal prevailing winds and their interrelationships with releases of nitrogen from point or nonpoint sources. Then, combined with focused vulnerability analysis models, resource managers would likely be better positioned to implement a more timely adaptive management process [126-128].

\section{Implications for Resource Managers and Future Research Needs}

Questions regarding current and future impacts of atmospheric deposition of nutrients and metals in the high latitudes of North America are many, particularly when multiple stressor exposures are predicated by uncertainties that underlie changes linked to shifting baselines associated with climate change $[92,129,130]$. As noted in preceding sections, increases in the deposition of nitrogen have been linked to several terrestrial ecological changes, including soil biogeochemistry, plant stress susceptibility, and community diversity. Critical effects have been linked to direct toxicity of nitrogen gases and aerosols to individual plant species. And singly or in conjunction with other stressors, soil-mediated effects on vegetation, increased susceptibility to competing stressors, and competitive changes in relationships between species have often times expressed themselves as loss of diversity. Based on available empirical data derived from public domain sources, deposition of nitrogen in selected venues in Interior Alaska suggest rates remain relatively low; however, these high-latitude habitats remain vulnerable to inputs that are contributing to a multiple stressors exposure potentially strongly affected by climate change. In part, these technical findings suggest adaptive management may be challenged by increasing nitrogen loads in NPS parklands that parallel increasing temperatures and spatially variable changes in precipitation which inevitably affect the landscape signatures across arctic and boreal habitats.

Low arctic landscapes in Alaska, Canada and Siberia are currently experiencing increases in shrub cover, pre- sumably in part due to climate change [131-133]. Resource managers have expressed concern that infilling of previously open-low shrub cover with tall shrubs (e.g., Alnus spp., Salix spp., Betula glandulosum) would decrease lichen cover in tundra ecosystems [134,135]. The Western Arctic Caribou Herd (WAH) is one of the largest free-ranging ungulate herds in North America, and subsists during the winter months almost exclusively on tundra lichens [136]. If slow-growing lichen winter range becomes outcompeted by faster growing shrubs, which additionally smother lichens with deciduous leaf drop, the caribou carrying capacity of the landscape is likely to drop dramatically. This carries consequences both for the ecosystem and for the traditional subsistence lifestyles of area communities. Increasing $\mathrm{N}$ deposition from emerging regional development would be likely to directly favor vascular plants and directly harm lichen abundance and diversity through acidification and overstimulation of the algal component of the lichen symbiosis $[29,137$, 138]. Lichens account for approximately $50 \%$ of the flora in the arctic national parks, and a co-dominant amount of biomass [135].

An increase in fire frequency has also been noted in western Alaska [134], and is probably linked to climate warming and an increase in lightning strikes [136]. Increasing $\mathrm{N}$ deposition would be likely to favor graminoids [4], which have high flammability. Post-fire vegetation return is heavily dominated by graminoids for the first 20 years in northwest Alaska, which could potentially strengthen positive feedback for shortened fire return interval [139]. Lichens would be extremely sparse in such a scenario. Although more local in scale, heavy metal enriched fugitive dusts have also had an impact on vegetation, in particular lichen communities [140]. As development of new mines and oil and gas deposits proceeds in the area, it will be important to monitor contaminant inputs on both local and regional scales as well as to adopt provisional empirical critical loads of $\mathrm{N}$ and selected metals to protect lichen communities.

\section{Future Research Needs}

Data synthesis. Comprehensive analyses and mapping of existing data could help to develop key questions which may be unique to Alaska and thereby narrow the focus of strategic planning activities for resource managers. To begin, a reconnaissance-level exploratory analysis of all current monitoring and assessment data from mosses and lichens of high-latitude areas of North America, especially NPS lands of interior and western Alaska, such as that previously done for limited 1990 - 1992 data [65] could lay the groundwork for characterizing nutrient or metal loads associated with atmospheric deposition in these areas. For example, in Figure $\mathbf{8}$ we used simple box plots 
to initially characterize some of the existing data for $\mathrm{Pb}$ concentrations in mosses and lichens collected on NPS lands in central and northwest Alaska. Tissue concentrations of $\mathrm{Pb}$ were previously determined in mosses ${ }^{1}$ collected from 24 sites across Arctic Alaska [65]; from multiple $1600-\mathrm{m}$ transects lying perpendicular to a lead-zinc mine haul road and from nearby reference sites [141,142] in Cape Krusenstern National Monument-one of the NPS western Arctic management areas - and finally at Denali National Park and Preserve located in Interior Alaska [107]. Notably, moss samples of the latter study were washed before analysis, but washing was not done with the other studies. In addition, to provide a comparative context for interpreting these preliminary outcomes of exploratory data analysis, we assembled existing data for lichens ${ }^{2}$ from Western Airborne Contaminants Assessment Project (WACAP); [143]. We also reviewed available literature from Arctic Monitoring and Assessment Program (AMAP), particularly that data available for metals linked to atmospheric deposition [102,144, 145]. Continued research in this area could help to identify paths toward improved characterization of elemental load $v$. tissue residue relationships, and the role that cryptogams play to better inform resource management of potential threats to NPS lands in western and interior.

In the example for $\mathrm{Pb}$ shown by Figure 8, we are presently unable to accurately quantify relationships between tissue residues in mosses or lichens and actual loads; however, these data demonstrate the utility of $H$. splendens for biomonitoring within interior Alaska. Results of those measurements clearly indicate a strong $\mathrm{Pb}$ gradient near a lead-zinc mine haul road and a $\mathrm{Pb}$ gradient near a coal-fired power plant. Furthermore, there was close agreement (reproducibility) between samples collected 5 years apart at reference locations, and those values were within the reference range determined about a decade previously. Ranges indicated for 3 lichen species indicate that they also have potential as $\mathrm{Pb}$ biomonitors, but may exhibit higher relative variability (Figure 8). Presently Hylocomium splendens is the primary cryptogam being monitored by NPS in Arctic Alaska; however, reliance on other cryptogams might be useful in some areas. If so, interpretation of biomonitoring data from different species of lichens and mosses will require greater charac-

\footnotetext{
${ }^{1}$ Splendid feather moss (Hylocomium splendens; Bryophyta/Musci/ Hylocomiaceae) is perennial moss, generally living 8 to 10 years. The moss is relatively large and commonly occurs in patches to form mats. Stems range between $10-15 \mathrm{~cm}$, and has filamentous rhizoids that can transport soil water for relatively long vertical distances to stems and green surface tissues.

${ }^{2}$ Silver-lined freckle-pelt (Peltigera aphthosa; lichenized fungi [mutualistic with algal photobionts; Ascomycetes/Peltigeraceae] is a foliose lichen with a large thallus, and Richardson's mansonhalea (Masonhalea richardsonii; lichenized fungi [mutualistic with algal photobionts; Ascomycetes/Parmeliaceae]) generally presents unattached and is wind-blown, frequently associated with mosses and often times collecting in well-drained depressions of hummocky tundra.
}

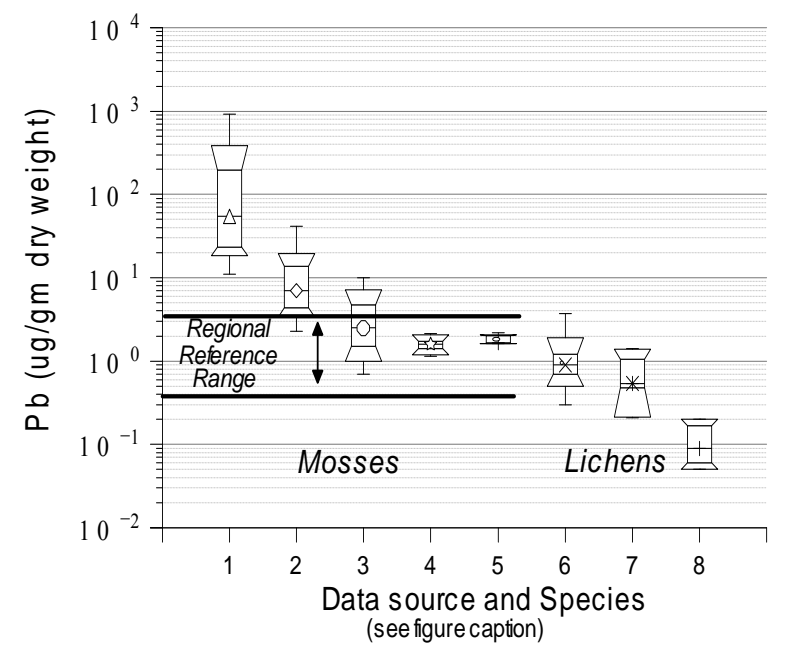

Figure 8. Tissue concentrations of lead $(\mathrm{Pb})$ represented by box-and-whisker plots for various species of moss and lichen collected in interior Alaska: (1 and 2) Hylocomium (H.) splendens collected in 2001 at distances of $\leq 1000 \mathrm{~m}$ and 1000 m to $1600 \mathrm{~m}$, respectively, from Red Dog lead-zinc minehaul road in Cape Krusenstern National Monument [142]; (3) $H$. splendens collected in or near Denali National Park and Reserve $\leq 50 \mathrm{~km}$ from a coal-fired power plant in 1991 [107]; (4 and 5) $H$. splendens collected at reference locations in Cape Krusenstern National Monument in 2001 [142] or 2006, respectively [140]; (6 - 8) lichen species Peltigera aphthosa, Flavocetraria cucullata, and Masonhalea richardsonii, collected between 2002 and 2007 in Denali National Park and Preserve, Gates of the Arctic National Park and Preserve, and Noatak National Preserve, respectively [143]. Regional reference range based on concentrations in $H$. splen-dens collected from 24 locations across Arctic Alaska during 1991 and 1992 [65].

terization of biological attributes likely to influence cryptogam exposure such as growth habit of pleurocarpous $\mathrm{v}$. acrocarpous mosses, or growth among different forms of lichens. Regardless, a preliminary synthesis of existing data available for high latitude areas of North America could underscore research needs, especially for lands experiencing multiple stressor exposures entangled with outcomes of climate change [92].

Impacts on ecosystem processes. Worldwide, reactive nitrogen has increased. Similarly, deposition of metals from atmospheric sources has increased, particularly in areas where energy development has been undertaken. Yet, dynamic effects on terrestrial vascular and non-vascular plants and communities are incompletely understood, especially exposure-effects relationships across biomes and habitats, and particularly in highly vulnerable areas. Such is the case with arctic and boreal regions of high-latitude North America where management-critical data gaps remain concerning linkages between increased depositional loads of atmospheric pollutants and disturbances to terrestrial ecosystems processes. For example, on the effects side of the ledger, questions related to my- 
corrhizal processes, plant disease, herbivory and competition, fertilization of arctic and boreal soils, and community structure recur as issues needing further research. Studies focusing on dynamics of elemental biogeochemical cycling within arctic terrestrial habitats are also needed. Such investigations are particularly important in the context of dynamically challenged ecosystems with multiple receptors exhibiting ranges of sensitivities to different stressors that frequently function within a landscape of competing risks. And, this is especially true in in the context of long-term model forecasting, given likely exposures increasing in parallel with climate-change linked alteration. For example, input of biologically reactive nitrogen to boreal and arctic ecosystems is usually highly limited, but increased inputs of nitrate and ammonia (as ammonium) from anthropogenic sources has fundamentally changed past interpretations of the role that these exogenous sources play in the system's function. Few vascular plants within these high-latitude systems are capable of forming symbiotic relations with $\mathrm{N}_{2}$-fixing microorganisms, yet common boreal forest $\mathrm{N}_{2}$ fixing lichens, bryophytes and Sphagnum spp. harbor $\mathrm{N}_{2}$-fixing cyanobacteria on leaf-surfaces [146]. Nitrogen fixed via this pathway subsequently becomes available to vascular plants once bryophytes decompose; consequently, degradation of nitrogen-fixing cryptogams communities may in turn stimulate growth and competition from vascular plants.

The link between empirical data and ecological modeling. In general, plant productivity and biological diversity of arctic (and alpine) ecosystems are highly influenced by $\mathrm{N}$ or metal phytotoxicity. However, studies focused on these regions in North America are relatively limited. Boreal coniferous forests, one of the largest forest zones at present, are poorly characterized with respect to $\mathrm{N}$ critical loadings. Recently, impacts on understory vegetation have received increased attention, but the numbers of published studies remain scant, with most focused on Scandinavian countries. Existing or potentially updated forecasts of critical loads for nitrogen or metals demand validation of spatiotemporal models used to characterize inputs of these atmospheric chemicals. Modeling spatial distributions of both effects on vegetation communities and atmospheric pollutant depositional loads attempts to overcome incomplete "on-the ground" data coverage, because observations of large-scale ecosystems responses to environmental changes are generally limited, existing for relatively short periods of time, and from only a few geographical regions. Consequently, derivation of improved CL models could prove to be an important tool for resource managers to leverage regulatory agencies towards reducing harmful atmospheric emissions. Practically speaking, empirical approaches for characterizing CLs present snapshots of a system at risk, and a simple time-series analysis of multiple snapshots could be used in the near term to help resource managers protect sensitive resources. However, to make reasonable predictions of ecosystem responses to environmental changes over time spans of tens to hundreds of years and over vast geographical regions, an increased awareness of model uncertainties must be incorporated into forecasting. Ongoing work should improve characterization of model dependencies and sensitivities to violations to underpinning assumptions, and an emphasis on monitoring design and increased collection of empirical data cannot be more strongly encouraged. European efforts (e.g., LRTAP and its working groups) have emphasized outstanding challenges for currently used forecasting models, challenges that might benefit from North American research focused on:

1) Increased sampling and spatial coverage in monitoring loads in Arctic Alaska;

2) Improved understanding of the dynamics of contaminant accumulation by mosses and their use for estimating critical loads;

3) More extensive testing and validation of existing models, particularly against long-term datasets;

4) Development of models or updates to existing models, including expanded testing and application beyond the geographical region for which model dose-response relationships have been parameterized, which would directly benefit resource managers of North America;

5) Evaluation of the possibility that wet deposition of atmospheric nitrogen may enhance establishment of invasive species and cause potential adverse effects on native species, including sensitive species of management concern;

6) Characterization of differential inputs of chemical species (e.g., $\mathrm{NO}_{3}$ versus $\mathrm{NH}_{3}$ or $\mathrm{NH}_{4}^{+}$), and the role these play in eliciting responses from vascular and nonvascular plant species.

Ultimately, collection of moss data combined with the development of refined CL values might be used to help guide future regulation of atmospheric contaminant sources potentially impacting Arctic Alaska. But first, additional long-term studies are needed to determine patterns of contaminant deposition as measured by moss biomonitors and to quantify ecosystem responses at particular loadings/ranges of contaminants within Arctic Alaska.

\section{Acknowledgements}

A big "thank you" to Julia Towns-Campbell for her efforts with literature searches and document retrievals in support this review. We are grateful to Susan Will-Wolf (University of Wisconsin-Madison) for extremely helpful suggestions for revision of an early draft and two anonymous reviewers for their thoughtful comments on the fi- 
nal draft.

\section{REFERENCES}

[1] S. G. Fancy, J. E. Gross and S. L. Carter, "Monitoring the Condition of Natural Resources in Us National Parks," Environmental Monitoring and Assessment, Vol. 151, No. 1-4, 2009, pp. 161-174.

http://dx.doi.org/10.1007/s10661-008-0257-y

[2] J. Nilsson and P. Grennfelt, "Critical Loads for Sulphur and Nitrogen: Report from a Workshop Held at Stockloster," UN/ECE and Nordic Council of Ministers, 19-24 March 1988.

[3] United Nations Economic Commission for Europe (UNECE), "Manual on Methodologies and Criteria for Modeling and Mapping Critical Loads and Levels and Air Pollution Effects, Risks, and Trends," Federal Environmental Agency (Umweltbundesamt), Berlin, 2004, p. 253.

[4] L. H. Pardo, M. E. Fenn, C. L. Goodale, L. H. Geiser, C. T. Driscoll, E. B. Allen, J. S. Baron, R. Bobbink, W. D. Bowman, C. M. Clark, B. Emmett, F. S. Gilliam, T. L. Greaver, S. J. Hall, E. A. Lilleskov, L. L. Liu, J. A. Lynch, K. J. Nadelhoffer, S. S. Perakis, M. J. Robin-Abbott, J. L. Stoddard, K. C. Weathers and R. L. Dennis, "Effects of Nitrogen Deposition and Empirical Nitrogen Critical Loads for Ecoregions of the United States," Ecological Applications, Vol. 21, No. 8, 2011, pp. 3049-3082.

http://dx.doi.org/10.1890/10-2341.1

[5] United Nations Economic Commission for Europe (UNECE), "Hemispheric Transport of Air Pollution," Air Pollution Studies No. 16, United Nations, Geneva, 2007, p. 165.

[6] United States Environmental Protection Agency (USEPA), "National Ambient Air Quality Standards (NAAQS)," 2011. www.epa.gov/air/criteria.html

[7] United States Environmental Protection Agency (USEPA), "Policy Assessment for the Review of the Secondary National Ambient Air Quality Standards for Nox and Sox: Second External Review Draft," U.S. Environmental Protection Agency, Research Triangle Park, NC, Washington, DC, 2010, p. 449.

[8] United States Environmental Protection Agency (USEPA), "Air Quality Planning and Standards," 2012.

http://www.epa.gov/oaqps001/

[9] United States Environmental Protection Agency (USEPA), "Mercury \& Air Toxics Standards," 2012. http://www.epa.gov/airquality/powerplanttoxics/

[10] G. J. Reinds, J. E. Groenenberg and W. de Vries, "Critical Loads of Copper, Nickel, Zinc, Arsenic, Chromium and Selenium for Terrestrial Ecosystems at a European Scale: A Preliminary Assessment," Alterra, Wageningen, 2006.

[11] J. Slootweg, J. P. Hettelingh, M. Posch, G. Schütze, T. Spranger, W. de Vries, G. J. Reinds, M. van't Zelfde, S. Dutchak and I. Ilyin, "European Critical Loads of Cadmium, Lead and Mercury and Their Exceedances," In: P. Brimblecombe, H. Hara, D. Houle and M. Novak, Eds., Acid Rain-Deposition to Recovery, Springer, Netherlands, 2007, pp. 371-377.

http://dx.doi.org/10.1007/978-1-4020-5885-1_41
[12] National Atmospheric Deposition Monitoring Program (NADP), "National Atmospheric Deposition Program/National Trends Network," 2012. http://nadp.sws.uiuc.edu

[13] C. E. Stephan, et al., "Guidelines for Deriving Numerical National Water Quality Criteria for the Protection of Aquatic Organisms and Their Uses, Epa 822/R-85/100," In: US Environmental Protection Agency, Office Research \& Development, Washington, DC, 1985, p. 104.

[14] S. Jovan, "Lichen Bioindication of Biodiversity, Air Quality, and Climate: Baseline Results from Monitoring in Washington, Oregon, and California,” In: U.S. Department of Agriculture, Forest Service, Pacific Northwest Research Station, Portland, 2008, p. 115.

[15] L. H. Pardo, "Approaches for Estimating Critical Loads of Nitrogen and Sulfur Deposition for Forest Ecosystems on US Federal Lands," In: Newtown Square, 2006, p. 25.

[16] M. E. Fenn, E. B. Allen, S. B. Weiss, S. Jovane, L. H. Geiser, G. S. Tonnesen, R. F. Johnson, L. E. Rao, B. S. Gimeno, F. Yuan, T. Meixner and A. Bytnerowicz, "Nitrogen Critical Loads and Management Alternatives for N-Impacted Ecosystems in California," Journal of Environmental Management, Vol. 91, No. 12, 2010, pp. 2404 2423. http://dx.doi.org/10.1016/j.jenvman.2010.07.034

[17] M. E. Fenn, S. Jovan, F. Yuan, L. Geiser, T. Meixner and B. S. Gimeno, "Empirical and Simulated Critical Loads for Nitrogen Deposition in California Mixed Conifer Forests," Environmental Pollution, Vol. 155, No. 3, 2008, pp. 492-511. http://dx.doi.org/10.1016/j.envpol.2008.03.019

[18] M. E. Fenn, "The Effects of Nitrogen Deposition, Ambient Ozone, and Climate Change on Forests in the Western US," In: C. Aguirre Bravo, Ed., Monitoring Science and Technology Symposium Proceedings Unifying Knowledge for Sustainability in the Western Hemisphere: Proceedings Rmrs-P-42cd, 20-24 September 2004, Denver, Co, USDA, Forest Service, Rocky Mountain Research Station, Fort Collins, 2006, pp. 2-8.

[19] D. A. Glavich and L. H. Geiser, "Potential Approaches to Developing Lichen-Based Critical Loads and Levels for Nitrogen, Sulfur and Metal-Containing Atmospheric Pollutants in North America," The Bryologist, Vol. 111, No. 4, 2008, pp. 638-649. http://dx.doi.org/10.1639/0007-2745-111.4.638

[20] L. Fisher, P. Mays and C. Wylie, "An Overview of Nitrogen Critical Loads for Policy Makers, Stakeholders, and Industries in the United States," Water, Air, \& Soil Pollution, Vol. 179, No. 1-4, 2007, pp. 3-18. http://dx.doi.org/10.1007/s11270-006-9235-6

[21] P. Hoegberg, H. Fan, M. Quist, D. Binkley and C. O. Tamm, "Tree Growth and Soil Acidification in Response to 30 Years of Experimental Nitrogen Loading on Boreal Forest," Global Change Biology, Vol. 12, No. 3, 2006, pp. 489-499. http://dx.doi.org/10.1111/j.1365-2486.2006.01102.x

[22] A. Nordin, J. Strengbom, J. Witzell, T. Näsholm and L. Ericson, "Nitrogen Deposition and the Biodiversity of Boreal Forests: Implications for the Nitrogen Critical Load," AMBIO: A Journal of the Human Environment, Vol. 34, No. 1, 2005, pp. 20-24.

[23] A. J. Gold and J. T. Sims, "Eutrophication," In: H. Daniel, Ed., Encyclopedia of Soils in the Environment, Elsevier, 
Oxford, 2005, pp. 486-494. http://dx.doi.org/10.1016/B0-12-348530-4/00093-X

[24] V. H. Smith, S. B. Joye and R. W. Howarth, "Eutrophication of Freshwater and Marine Ecosystems," Limnology and Oceanography, Vol. 51, No. 1, 2006, pp. 351-355.

[25] J. Aber, et al., "Forest Processes and Global Environmental Change: Predicting the Effects of Individual and Multiple Stressors," BioScience, Vol. 51, No. 9, 2001, pp. 735-751.

http://dx.doi.org/10.1641/0006-3568(2001)051[0735:FPA GEC]2.0.CO;2

[26] M. Hornung, H. Dyke, J. R. Hall and S. E. Metcalfe, "The Critical Load Approach to Air Pollution Control," In: R. E. Hester and R. M. Harrison, Eds., Air Quality Management, The Royal Society of Chemistry, London, 1997, pp. 119-140.

http://dx.doi.org/10.1039/9781847550101-00119

[27] R. Bobbink and J. P. Hettelingh, "Review and Revision of Empirical Critical Loads and Dose-Response Relationships: Proceedings of an Expert Workshop, Noordwijkerhout, 23-25 June 2010," In: Coordination Centre for Effects, National Institute for Public Health and the Environment (RIVM), Bilthoven, The Netherlands, 2011, p. 244.

[28] R. Bobbink, K. Hicks , J. Galloway, T. Spranger, R. Alkemade, M. Ashmore, M. Bustamante, S. Cinderby, E. Davidson, F. Dentener, B. Emmett, J. W. Erisman, M. Fenn, F. Gilliam, A. Nordin, L. Pardo and W. De Vries, "Global Assessment of Nitrogen Deposition Effects on Terrestrial Plant Diversity: A Synthesis," Ecological Applications, Vol. 20, No. 1, 2010, pp. 30-59. http://dx.doi.org/10.1890/08-1140.1

[29] L. H. Geiser, S. E. Jovan, D. A. Glavich and M. K. Porter, "Lichen-Based Critical Loads for Atmospheric Nitrogen Deposition in Western Oregon and Washington Forests, USA," Environmental Pollution, Vol. 158, No. 7, 2010, pp. 2412-2421.

http://dx.doi.org/10.1016/j.envpol.2010.04.001

[30] L. H. Geiser and P. N. Neitlich, "Air Pollution and Climate Gradients in Western Oregon and Washington Indicated by Epiphytic Macrolichens," Environmental Pollution, Vol. 145, No. 1, 2007, pp. 203-218. http://dx.doi.org/10.1016/i.envpol.2006.03.024

[31] L. H. Pardo, “Assessment of Nitrogen Deposition Effects and Empirical Critical Loads of Nitrogen for Ecoregions of the United States, Chapter 19," In: L. H. Pardo, M. J. Robin-Abbott and C. T. Driscoll, Eds., United States Department of Agriculture, Forest Service, Northern Research Station, General Technical Report NRS-80, Newtown Square, 2011.

[32] B. Achermann and R. Bobbink, "Empirical Critical Loads for Nitrogen," Proceedings of Expert Workshop, Berne, Switzerland, 11-13 November 2002, In: Swiss Agency for the Environment, Forests and Landscape (SAEFL), Berne, 2003, p. 327.

[33] W. De Vries and J. E. Groenenberg, "Evaluation of Approaches to Calculate Critical Metal Loads for Forest Ecosystems," Environmental Pollution, Vol. 157, No. 12, 2009, pp. 3422-3432. http://dx.doi.org/10.1016/j.envpol.2009.06.021

[34] J. R. Hall, M. Ashmore, J. Fawehinmi, C. Jordan, S. Lofts, L. Shotbolt, D. J. Spurgeon, C. Svendsen and E. Tipping, "Developing a Critical Load Approach for National Risk Assessments of Atmospheric Metal Deposition," Environmental Toxicology and Chemistry, Vol. 25, No. 3, 2006, pp. 883-890. http://dx.doi.org/10.1897/04-571R.1

[35] W. De Vries and D. J. Bakker, "Manual for Calculating Critical Loads of Heavy Metals for Terrestrial Ecosystems: Guidelines for Critical Limits, Calculation Methods and Input Data," DLO Winand Staring Centre, Wageningen, 1998.

[36] W. De Vries, D. J. Bakker, J. E. Groenenberg, G. J. Reinds, J. Bril and J. A. van Jaarsveld, "Calculation and Mapping of Critical Loads for Heavy Metals and Persistent Organic Pollutants for Dutch Forest Soils," Journal of Hazardous Materials, Vol. 61, No. 1-3, 1998, pp. 99106. http://dx.doi.org/10.1016/S0304-3894(98)00113-7

[37] W. De Vries, G. Schuetze, Steve Lofts, E. W. Tipping, M. Meili, P. F. A. M. Roemkens and J. E. Groenenberg, "Calculation of Critical Loads for Cadmium, Lead and Mercury: Background Document to a Mapping Manual on Critical Loads of Cadmium, Lead and Mercury," Alterra, Wageningen, 2005.

[38] S. Lofts, "Critical Loads of Metals and Other Trace Elements to Terrestrial Environments," Environmental Science \& Technology, Vol. 41, No. 18, 2007, pp. 6326-6331. http://dx.doi.org/10.1021/es0726106

[39] J. Slootweg, J. P. Hettelingh, M. Posch, S. Dutchak, I. Ilyin, "Critical Loads of Cadmium, Lead and Mercury in Europe," In: Report 259101015/2005, Netherlands Environmental Assessment Agency, Bilthoven, 2005, p. 145.

[40] M. Ashmore, et al., "Further Development of an Effect (Critical Loads) Based Approach for Cadmium, Copper, Lead and Zinc," In: Department for Environment, Food and Rural Affairs, London, 2004, p. 130.

[41] J. P. Hettelingh, M. Posch and J. Slootweg, "Critical Load, Dynamic Modelling and Impact Assessment in Europe: Cce Status Report 2008," In: Netherlands Environmental Assessment Agency, Bilthoven, 2008, p. 231.

[42] M. Posch and W. De Vries, "Dynamic Modelling of Metals-Time Scales and Target Loads," Environmental Modelling \& Software, Vol. 24, No. 1, 2009, pp. 86-95. http://dx.doi.org/10.1016/j.envsoft.2008.05.007

[43] H. E. Allen, "Bioavailability of Metals in Terrestrial Ecosystems: Importance of Partitioning for Bioavailability to Invertebrates, Microbes, and Plants," SETAC Press, Pensacola, 2002, p. 158.

[44] German Federal Environmental Protection Agency (Umweltbundesamt), "Critical Loads for Heavy Metals," In: T. Spranger, U. Lorenz and H.-D. Gregor, Manual on Methodologies and Criteria for Modelling and Mapping Critical Loads \& Levels and Air Pollution Effects, Risks and Trends, 2004, $266 \mathrm{p}$.

http://www.umweltbundesamt.de/en/publikationen/manua 1-on-methodologies-criteria-for-modelling

[45] J. Slootweg, M. Posch and J. P. Hettelingh, "Progress in 
the Modelling of Critical Thresholds, Impacts to Plant Species Diversity and Ecosystem Services in Europe: Cce Status Report 2010," Coordination Centre for Effects, 2010, p. 186.

[46] M. M. Savard, G. F. Bonham-Carter and C. M. Banic, "A Geoscientific Perspective on Airborne Smelter Emissions of Metals in the Environment: An Overview," Geochemistry: Exploration, environment, analysis, Vol. 6, No. 2-3, 2006, pp. 99-109.

http://dx.doi.org/10.1144/1467-7873/05-095

[47] M. Conti and G. Cecchetti, "Biological Monitoring: Lichens as Bioindicators of Air Pollution Assessment-A Review," Environmental Pollution, Vol. 114, No. 3, 2001, pp. 471-492. http://dx.doi.org/10.1016/S0269-7491(00)00224-4

[48] A. Rühling and G. Tyler, "Sorption and Retention of Heavy Metals in the Woodland Moss Hylocomium Splendens (Hebw.) Br. Et Sch,” Oikos, Vol. 21, No. 1, 1970, pp. 92-97. http://dx.doi.org/10.2307/3543844

[49] E. Steinnes, "Biomonitors of Air Pollution by Heavy Metals," Control and Fate of Atmospheric Trace Metals, Kluwer Academic Publishers, Dordrecht, 1989, p. 321.

[50] H. Harmens, et al., "Mosses as Biomonitors of Atmospheric Heavy Metal Deposition: Spatial Patterns and Temporal Trends in Europe," Environmental Pollution, Vol. 158, No. 10, 2010, pp. 3144-3156.

http://dx.doi.org/10.1016/i.envpol.2010.06.039

[51] Z. Jeran, R. Jacimovic and P. Pavsic Mikuz, "Lichens and Mosses as Biomonitors," Journal de Physique IV (Proceedings), Vol. 107, No. 1, 2003, pp. 675-678.

[52] K. Szczepaniak and M. Biziuk, "Aspects of the Biomonitoring Studies Using Mosses and Lichens as Indicators of Metal Pollution," Environmental Research, Vol. 93, No. 3, 2003, pp. 221-230. http://dx.doi.org/10.1016/S0013-9351(03)00141-5

[53] B. Wolterbeek, "Biomonitoring of Trace Element Air Pollution: Principles, Possibilities and Perspectives," Environmental Pollution, Vol. 120, No. 1, 2002, pp. 11-21. http://dx.doi.org/10.1016/S0269-7491(02)00124-0

[54] H. G. Zechmeister, K. Grodzińska and G. Szarek-Łukaszewska, "Bryophytes," In: A. M. Breure, B. A. Markert and H. G. Zechmeister, Eds., Bioindicators and Biomonitors: Principles, Concepts and Applications, Oxford, 2003, pp. 329-375.

[55] P. C. Onianwa, "Monitoring Atmospheric Metal Pollution: A Review of the Use of Mosses as Indicators," Environmental Monitoring and Assessment, Vol. 71, No. 1, 2001, pp. 13-50. http://dx.doi.org/10.1023/A:1011660727479

[56] J. W. Bates, "Mineral Nutrition, Substratum Ecology, and Pollution," In: A. J. Shaw and B. Goffinet, Eds., Bryophyte Ecology, Cambridge University Press, Cambridge, 2000, pp. 248-311.

[57] M. C. F. Proctor, "Physiological Ecology," In: A. J. Shaw and B. Goffinet, Eds., Bryophyte Biology, Cambridge University Press, Cambridge, 2000, pp. 225-247. http://dx.doi.org/10.1017/CBO9781139171304.009

[58] J. R. Aboal, J. A. Fernandez, T. Boquete and A. Carballeira, "Is It Possible to Estimate Atmospheric Deposi- tion of Heavy Metals by Analysis of Terrestrial Mosses?" Science of the Total Environment, Vol. 408, No. 24, 2010, pp. 6291-6297.

http://dx.doi.org/10.1016/j.scitotenv.2010.09.013

[59] T. Berg and E. Steinnes, "Is It Possible to Estimate Atmospheric Deposition of Heavy Metals by Analysis of Terrestrial Mosses?...(Rebuttal)," In: Book of Abstracts, p 9, 24th Task Force Meeting ICP Vegetation, RapperswilJona, SWI, 31 January-3 February 2011. http://nora.nerc.ac.uk/13976/

[60] J. R. Aboal, A. Pérez-Llamazares, A. Carballeira, S. Giordano and J. A. Fernández, "Should Moss Samples Used as Biomonitors of Atmospheric Contamination Be Washed?" Atmospheric Environment, Vol. 45, 2011, pp. 6837-6840. http://dx.doi.org/10.1016/j.atmosenv.2011.09.004

[61] C. Reimann, H. Niskavaarab, G. Kashulinac, P. Filzmoserd, R. Boyda, T. Voldena, O. Tomilinae and I. Bogatyreve, "Critical Remarks on the Use of Terrestrial Moss (Hylocomium splendens and Pleurozium schreberi) for Monitoring of Airborne Pollution," Environmental Pollution, Vol. 113, No. 1, 2001, pp. 41-57. http://dx.doi.org/10.1016/S0269-7491(00)00156-1

[62] M. Boquete, J. Fernández, J. Aboal, C. Real and A. Carballeira, "Spatial Structure of Trace Elements in Extensive Biomonitoring Surveys with Terrestrial Mosses," Science of the Total Environment, Vol. 408, No. 1, 2009, pp. 153-162. http://dx.doi.org/10.1016/j.scitotenv.2009.09.017

[63] M. T. Boquete, J. A. Fernández, J. R. Aboal and A. Carballeira, "Analysis of Temporal Variability in the Concentrations of Some Elements in the Terrestrial Moss Pseudoscleropodium purum," Environmental and Experimental Botany, Vol. 72, No. 2, 2011, pp. 210-216. http://dx.doi.org/10.1016/j.envexpbot.2011.03.002

[64] E. Steinnes, "A Critical Evaluation of the Use of Naturally Growing Moss to Monitor the Deposition of Atmospheric Metals," Science of the Total Environment, Vol. 160-161, No. 1, 1995, pp. 243-249. http://dx.doi.org/10.1016/0048-9697(95)04360-D

[65] J. Ford, D. Landers, D. Kugler, B. Lasorsa, S. Allen-Gil, E. Crecelius and J. Martinson, "Inorganic Contaminants in Arctic Alaskan Ecosystems: Long-Range Atmospheric Transport or Local Point Sources?" Science of the Total Environment, Vol. 160, No. 1, 1995, pp. 323-335.

[66] L. González-Miqueo, D. Elustondo, E. Lasheras and J. M. Santamaría, "Use of Native Mosses as Biomonitors of Heavy Metals and Nitrogen Deposition in the Surroundings of Two Steel Works," Chemosphere, Vol. 78, No. 8, 2010, pp. 965-971.

http://dx.doi.org/10.1016/j.chemosphere.2009.12.028

[67] H. Harmens, et al., "Nitrogen Concentrations in Mosses Indicate the Spatial Distribution of Atmospheric Nitrogen Deposition in Europe," Environmental Pollution, Vol. 159, No. 10, 2011, pp. 2852-2860. http://dx.doi.org/10.1016/j.envpol.2011.04.041

[68] E. Steinnes, T. Berg and H. T. Uggerud, “Three Decades of Atmospheric Metal Deposition in Norway as Evident from Analysis of Moss Samples," Science of the Total Environment, Vol. 412-413, No. 12, 2011, pp. 351-358. 
http://dx.doi.org/10.1016/j.scitotenv.2011.09.086

[69] M. Aceto, O. Abollino, R. Conca, M. Malandrino, E. Mentasti and C. Sarzanini, "The Use of Mosses as Environmental Metal Pollution Indicators," Chemosphere, Vol. 50, No. 3, 2003, pp. 333-342. http://dx.doi.org/10.1016/S0045-6535(02)00533-7

[70] S. Chakrabortty and G. T. Paratkar, "Biomonitoring of Trace Element Air Pollution Using Mosses," Aerosol and Air Quality Research, Vol. 6, No. 3, 2006, pp. 247-258.

[71] T. Berg and E. Steinnes, "Use of Mosses (Hylocomium splendens and Pleurozium schreberi) as Biomonitors of Heavy Metal Deposition: From Relative to Absolute Deposition Values," Environmental Pollution, Vol. 98, No. 1, 1997, pp. 61-71. http://dx.doi.org/10.1016/S0269-7491(97)00103-6

[72] D. Čeburnis and D. Valiulis, "Investigation of Absolute Metal Uptake Efficiency from Precipitation in Moss," Science of the Total Environment, Vol. 226, No. 2-3, 1999, pp. 247-253.

http://dx.doi.org/10.1016/S0048-9697(98)00399-4

[73] C. Reimann, A. Arnoldussen, R. Boyd, T. E. Finne, Ø. Nordgulen, T. Volden and P. Englmaier, "The Influence of a City on Element Contents of a Terrestrial Moss ( $\mathrm{Hy}$ locomium splendens)," Science of the Total Environment, Vol. 369, No. 1-3, 2006, pp. 419-432. http://dx.doi.org/10.1016/j.scitotenv.2006.04.026

[74] J. A. Couto, J. A. Fernández, J. R. Aboal and A. Carballeira, "Active Biomonitoring of Element Uptake with Terrestrial Mosses: A Comparison of Bulk and Dry Deposition," Science of the Total Environment, Vol. 324, No. 1, 2004, pp. 211-222.

http://dx.doi.org/10.1016/j.scitotenv.2003.10.024

[75] H. Harmens, et al., "Country-Specific Correlations across Europe between Modelled Atmospheric Cadmium and Lead Deposition and Concentrations in Mosses," Environmental Pollution, Vol. 166, No. 7, 2012, pp. 1-9. http://dx.doi.org/10.1016/j.envpol.2012.02.013

[76] H. Harmens, G. Mills, F. Hayes and D. Norris, "Air Pollution and Vegetation. ICP Vegetation Annual Report 2010/ 2011," NERC/Centre for Ecology \& Hydrology, 2011.

[77] S. Güsewell, "N: P Ratios in Terrestrial Plants: Variation and Functional Significance," New Phytologist, Vol. 164, No. 2, 2004, pp. 243-266. http://dx.doi.org/10.1111/j.1469-8137.2004.01192.x

[78] T. Nash, "Nutrients, Elemental Accumulation and Mineral Cycling, In," In: T. Nash, Ed., Lichen Biology, Cambridge University Press, Cambridge, 2008. http://dx.doi.org/10.1017/CBO9780511790478.013

[79] E. A. Paul, "Soil Microbiology, Ecology, and Biochemistry," Academic Press, Boston, 2007, p. 532.

[80] T. Liengen and R. A. Olsen, "Nitrogen Fixation by FreeLiving Cyanobacteria from Different Coastal Sites in a High Arctic Tundra, Spitsbergen," Arctic and Alpine Research, Vol. 29, No. 4, 1997, pp. 470-477. http://dx.doi.org/10.2307/1551994

[81] D. A. Lipson, S. K. Schmidt and R. K. Monson, "Links between Microbial Population Dynamics and Nitrogen Availability in an Alpine Ecosystem," Ecology, Vol. 80,
No. 5, 1999, pp. 1623-1631.

http://dx.doi.org/10.1890/0012-9658(1999)080[1623:LB MPDA]2.0.CO;2

[82] D. R. Nemergut, A. R. Townsend, S. R. Sattin, K. R. Freeman, N. Fierer, J. C. Neff, W. D. Bowman, C. W. Schadt, M. N. Weintraub and S. K. Schmidt, "The Effects of Chronic Nitrogen Fertilization on Alpine Tundra Soil Microbial Communities: Implications for Carbon and Nitrogen Cycling," Environmental Microbiology, Vol. 10, No. 11, 2008, pp. 3093-3105.

[83] A. Nordin, I. K. Schmidt and G. R. Shaver, "Nitrogen Uptake by Arctic Soil Microbes and Plants in Relation to Soil Nitrogen Supply," Ecology, Vol. 85, No. 4, 2004, pp. 955-962. http://dx.doi.org/10.1890/03-0084

[84] C. Gordon, J. Wynn and S. Woodin, "Impacts of Increased Nitrogen Supply on High Arctic Heath: The Importance of Bryophytes and Phosphorus Availability," New Phytologist, Vol. 149, No. 3, 2001, pp. 461-471. http://dx.doi.org/10.1046/j.1469-8137.2001.00053.x

[85] G. R. Shaver and F. S. Chapin, "Response to Fertilization by Various Plant Growth Forms in an Alaskan Tundra: Nutrient Accumulation and Growth," Ecology, Vol. 61, No. 3, 1980, pp. 662-675. http://dx.doi.org/10.2307/1937432

[86] M. Hornung and M. A. Sutton, "Impacts of Nitrogen Deposition in Terrestrial Ecosystems," Atmospheric Environment, Vol. 29, No. 22, 1995, pp. 3395-3396. http://dx.doi.org/10.1016/1352-2310(95)00215-K

[87] J. Gornall, I. Jónsdóttir, S. Woodin and R. Van der Wal, "Arctic Mosses Govern Below-Ground Environment and Ecosystem Processes,” Oecologia, Vol. 153, No. 4, 2007, pp. 931-941. http://dx.doi.org/10.1007/s00442-007-0785-0

[88] P. Laj, J. M. Palais and H. Sigurdsson, "Changing Sources of Impurities to the Greenland Ice Sheet over the Last 250 Years," Atmospheric Environment. Part A. General Topics, Vol. 26, No. 14, 1992, pp. 2627-2640. http://dx.doi.org/10.1016/0960-1686(92)90114-Z

[89] A. Neftel, J. Beer, H. Oeschger, F. Zurcher and R. C. Finkel, "Sulphate and Nitrate Concentrations in Snow from South Greenland 1895-1978," Nature, Vol. 314, No. 6012, 1985, pp. 611-613. http://dx.doi.org/10.1038/314611a0

[90] W. L. Chapman and J. E. Walsh, "Recent Variations of Sea Ice and Air Temperature in High Latitudes," Bulletin of the American Meteorological Society, Vol. 74, No. 1, 1993, pp. 33-47.

[91] I. S. Jónsdóttir, T. V. Callaghan and J. A. Lee, "Fate of Added Nitrogen in a Moss-Sedge Arctic Community and Effects of Increased Nitrogen Deposition," Science of the Total Environment, Vol. 160-161, No. 1, 1995, pp. 677685.

[92] L. D. Hinzman, N. D. Bettez, W. R. Bolton, et al., "Evidence and Implications of Recent Climate Change in Northern Alaska and Other Arctic Regions," Climatic Change, Vol. 72, No. 3, 2005, pp. 251-298. http://dx.doi.org/10.1007/s10584-005-5352-2

[93] A. Katttenberg and J. Mitchell, "Climate Models-Projec- 
tions of Future Climate," Climate Change 1995: The Science of Climate Change, Cambridge Univeristy Press, Cambridge, 1996, pp. 285-358.

[94] W. R. Rouse, M. S. V. Douglas, R. E. Hecky, A. E. Hershey, G. W. Kling, L. Lesack, P. Marsh, M. Mcdonald, B. J. Nicholson, N. T. Roulet and J. P. Smol, "Effects of Climate Change on the Freshwaters of Arctic and Subarctic North America," Hydrological Processes, Vol. 11, No. 8, 1997, pp. 873-902.

http://dx.doi.org/10.1002/(SICI)1099-1085(19970630)11: 8<873::AID-HYP510>3.0.CO;2-6

[95] K. J. Nadelhoffer, A. E. Giblin, G. R. Shaver and J. A. Laundre, "Effects of Temperature and Substrate Quality on Element Mineralization in Six Arctic Soils," Ecology, Vol. 72, No. 1, 1991, pp. 242-253. http://dx.doi.org/10.2307/1938918

[96] K. J. Nadelhoffer and J. W. Raich, "Fine Root Production Estimates and Belowground Carbon Allocation in Forest Ecosystems," Ecology, Vol. 73, No. 4, 1992, pp. 11391147. http://dx.doi.org/10.2307/1940664

[97] C. H. Robinson, P. A. Wookey, J. A. Lee, T. V. Callaghan and M. C. Press, "Plant Community Responses to Simulated Environmental Change at a High Arctic Polar SemiDesert," Ecology, Vol. 79, No. 3, 1998, pp. 856-866. http://dx.doi.org/10.1890/0012-9658(1998)079[0856:PCR TSE]2.0.CO;2

[98] C. Robinson, P. A. Wookey, A. N. Parsons, J. A. Potter, T. V. Callaghan, J. A. Lee, M. C. Press and J. M. Welker, "Responses of Plant Litter Decomposition and Nitrogen Mineralisation to Simulated Environmental Change in a High Arctic Polar Semi-Desert and a Subarctic Dwarf Shrub Heath," Oikos, Vol. 74, No. 3, 1995, pp. 503-512. http://dx.doi.org/10.2307/3545996

[99] D. A. Jaffe and M. D. Zukowski, "Nitrate Deposition to the Alaskan Snowpack," Atmospheric Environment. Part A. General Topics, Vol. 27, No. 17-18, 1993, pp. 29352941. http://dx.doi.org/10.1016/0960-1686(93)90326-T

[100] M. Nenonen, "Report on Acidification in the Arctic Countries: Man-Made Acidification in a World of Natural Extremes," In: The State of the Arctic Environment: Reports, Arctic Centre, University of Lapland, Rovaniemi, 1991, pp. 7-81.

[101] S. J. Woodin, "Effects of Acid Deposition on Arctic Vegetation," In: S. J. Woodin and M. Mick, Eds., Ecology of Arctic Environments, Blackwell Science, Oxford, 1997, pp. 21-240.

[102] Arctic Monitoring and Assessment Program (AMAP), "Arctic Pollution Issues: A State of the Arctic Environment Report," In: Arctic Monitoring and Assessment Programme (AMAP), Oslo, Norway, 1997, p. xii+188.

[103] F. S. I. Chapin, M. Oswood, K. Van Cleve, L. A. Viereck and D. L. Verbyla, "Alaska's Changing Boreal Forest," Oxford University Press, New York, 2006.

[104] L. Biegler, G. Biros (Editor), O. Ghattas, M. Heinkenschloss, D. Keyes, B. Mallick, L. Tenorio, B. van Bloemen Waanders, K. Willcox and Y. Marzouk, "Large-Scale Inverse Problems and Quantification of Uncertainty," John Wiley \& Sons, Chichester, 2011, p. 372.

[105] M. Forsius, M. Posch, J. Aherne, G. J. Reinds, J. Chris- tensen, L. Hole, "Assessing the Impacts of Long-Range Sulfur and Nitrogen Deposition on Arctic and Sub-Arctic Ecosystems," AMBIO: A Journal of the Human Environment, Vol. 39, No. 2, 2010, pp. 136-147.

[106] N. Gruber and J. N. Galloway, "An Earth-System Perspective of the Global Nitrogen Cycle," Nature, Vol. 451, No. 7176, 2008, pp. 293-296. http://dx.doi.org/10.1038/nature06592

[107] J. G. Crock, et al., "Element Concentrations and Trends for Moss, Lichen, and Surface Soils in and near Denali National Park and Preserve, Alaska, Open-File Report 92-323," In: US Department of the Interior, US Geological Survey, Reston, 1992.

[108] Z. M. Migaszewski, A. Gałuszka, J. G. Crock, P. J. Lamothe and S. Dołęgowska, "Interspecies and Interregional Comparisons of the Chemistry of Pahs and Trace Elements in Mosses Hylocomium Splendens (Hedw.) Bsg and Pleurozium Schreberi (Brid.) Mitt. From Poland and Alaska," Atmospheric Environment, Vol. 43, No. 7, 2009, pp. 1464-1473.

http://dx.doi.org/10.1016/j.atmosenv.2008.11.035

[109] M. R. Turetsky, "The Role of Bryophytes in Carbon and Nitrogen Cycling," The Bryologist, Vol. 106, No. 3, 2003, pp. 395-409. http://dx.doi.org/10.1639/05

[110] P. M. Vitousek, S. Porder, B. Z. Houlton and O. A. Chadwick, "Terrestrial Phosphorus Limitation: Mechanisms, Implications, and Nitrogen-Phosphorus Interactions," Ecological Applications, Vol. 20, No. 1, 2010, pp. 5-15. http://dx.doi.org/10.1890/08-0127.1

[111] J. H. C. Cornelissen, T. V. Callaghan, J. M. Alatalo, A. Michelsen, E. Graglia, A. E. Hartley, D. S. Hik, S. E. Hobbie, M. C. Press, C. H. Robinson, G. H. R. Henry, G. R. Shaver, G. K. Phoenix, D. Gwynn Jones, S. Jonasson, F. S. Chapin III, U. Molau, C. Neil, J. A. Lee, J. M. Melillo, B. Sveinbjörnsson and R. Aerts "Global Change and Arctic Ecosystems: Is Lichen Decline a Function of Increases in Vascular Plant Biomass?" Journal of Ecology, Vol. 89, No. 6, 2004, pp. 984-994. http://dx.doi.org/10.1111/j.1365-2745.2001.00625.x

[112] C. F. Dormann and S. J. Woodin, "Climate Change in the Arctic: Using Plant Functional Types in a Meta-Analysis of Field Experiments," Functional Ecology, Vol. 16, No. 1, 2002, pp. 4-17.

http://dx.doi.org/10.1046/j.0269-8463.2001.00596.x

[113] S. Jonasson, M. Havström, M. Jensen and T. V. Callaghan, "In Situ Mineralization of Nitrogen and Phosphorus of Arctic Soils after Perturbations Simulating Climate Change," Oecologia, Vol. 95, No. 2, 1993, pp. 179-186. http://dx.doi.org/10.1007/BF00323488

[114] R. Bobbink and J. G. M. Roelofs, "Nitrogen Critical Loads for Natural and Semi-Natural Ecosystems: The Empirical Approach," Water, Air, \& Soil Pollution, Vol. 85, No. 4, 1995, pp. 2413-2418. http://dx.doi.org/10.1007/BF01186195

[115] R. Bobbink and L. P. M. Lamers, "Effects of Increased Nitrogen Deposition," In: J. N. B. Bell and M. Treshow, Eds., Air Pollution and Plant Life, John Wiley \& Sons, Ltd., New York, 2002, pp. 201-235.

[116] J. T. Morris, "Effects of Nitrogen Loading on Wetland 
Ecosystems with Particular Reference to Atmospheric Deposition," Annual Review of Ecology and Systematics, Vol. 22, No. 1, 1991, pp. 257-279. http://dx.doi.org/10.1146/annurev.es.22.110191.001353

[117] J. N. Galloway, F. J. Dentener, D. G. Capone, E. W. Boyer, R. W. Howarth, S. P. Seitzinger, G. P. Asner, C. C. Cleveland, P. A. Green, E. A. Holland, D. M. Karl, A. F. Michaels, J. H. Porter, A. R. Townsend and C. J. Vöosmarty, "Nitrogen Cycles: Past, Present, and Future," Biogeochemistry, Vol. 70, No. 2, 2004, pp. 153-226. http://dx.doi.org/10.1007/s10533-004-0370-0

[118]F. Berendse and R. Aerts, "Competition between Erica Tetralix L. And Molinia Caerulea (L.) Moench. As Affected by the Availability of Nutrients," Acta Oecologia/Oecologia Plantarum, Vol. 5, No. 1, 1984, pp. 3-14.

[119] M. C. Nilsson, D. A. Wardle, O. Zackrisson and A. Jäderlund, "Effects of Alleviation of Ecological Stresses on an Alpine Tundra Community over an Eight-Year Period," Oikos, Vol. 97, No. 1, 2002, pp. 3-17. http://dx.doi.org/10.1034/j.1600-0706.2002.970101.x

[120] R. Bobbink, M. Hornung and J. G. M. Roelofs, "The Effects of Air-Borne Nitrogen Pollutants on Species Diversity in Natural and Semi-Natural European Vegetation," Journal of Ecology, Vol. 86, No. 5, 2003, pp. 717738.

http://dx.doi.org/10.1046/j.1365-2745.1998.8650717.x

[121] C. E. Mitchell, P. B. Reich, D. Tilman and J. V. Groth, "Effects of Elevated $\mathrm{CO}_{2}$, Nitrogen Deposition, and Decreased Species Diversity on Foliar Fungal Plant Disease," Global Change Biology, Vol. 9, No. 3, 2003, pp. 438-451. http://dx.doi.org/10.1046/j.1365-2486.2003.00602.x

[122] M. E. Fenn and M. A. Poth, "Monitoring Nitrogen Deposition in Throughfall Using Ion Exchange Resin Columns," Journal of Environmental Quality, Vol. 33, No. 6, 2004, pp. 2007-2014.

http://dx.doi.org/10.2134/jeq2004.2007

[123] W. G. Brumbaugh, S. Earhart, G. Linder and P. N. Neitlich, "Determination of Annual Loads of Inorganic Atmospheric Contaminants in Northern Alaska by Measurement in Snowpack and Passive Ion Collectors. [Abstract W262]," In: Abstract Book, SETAC North America 33th Annual Meeting, 11-15 November 2012, SETAC, Long Beach, 2012, p. 354.

[124] C. T. Allen, G. S. Young and S. E. Haupt, "Improving Pollutant Source Characterization by Better Estimating Wind Direction with a Genetic Algorithm," Atmospheric Environment, Vol. 41, No. 11, 2007, pp. 2283-2289. http://dx.doi.org/10.1016/j.atmosenv.2006.11.007

[125] B. B. Hicks, "Planning for Air Quality Concerns of the Future," Pure and Applied Geophysics, Vol. 160, No. 1-2, 2003, pp. 57-74. http://dx.doi.org/10.1007/s00024-003-8765-8

[126] C. J. Walters, “Adaptive Management of Renewable Resources," Macmillan, New York, 1986.

[127] C. J. Walters and R. Hilborn, "Ecological Optimization and Adaptive Management," Annual Review of Ecology and Systematics, Vol. 9, 1978, pp. 157-188.

[128] B. K. Williams, S. R. C. and S. C. D., “Adaptive Man- agement: The US Department of the Interior Technical Guide," US Department of the Interior, Adaptive Management Working Group, 2009.

[129] R. Corell, P. Prestrud, G. Weller, P. A. Anderson, et al., "Impacts of a Warming Arctic-Arctic Climate Impact Assessment," Cambridge University Press, Cambridge, 2004.

[130] E. Post, M. C. Forchhammer, M. S. Bret-Harte, T. V. Callaghan, T. R. Christensen, B. Elberling, A. D. Fox, O. Gilg, D. S. Hik, T. T. Høye, R. A. Ims, E. Jeppesen, D. R. Klein, J. Madsen, A. D. McGuire, S. Rysgaard, D. E. Schindler, I. Stirling, M. P. Tamstorf, N. J. Tyler, R. van der Wal, J. Welker, P. A. Wookey, N. M. Schmidt and P. Aastrup, "Ecological Dynamics across the Arctic Associated with Recent Climate Change," Science, Vol. 325, No. 5946, 2009, pp. 1355-1358.

[131] I. H. Myers-Smith, B. C Forbes, M. Wilmking, et al., "Shrub Expansion in Tundra Ecosystems: Dynamics, Impacts and Research Priorities," Environmental Research Letters, Vol. 6, No. 4, 2011, Article ID: 045509. http://dx.doi.org/10.1088/1748-9326/6/4/045509

[132] K. Tape, M. Sturm and C. Racine, "The Evidence for Shrub Expansion in Northern Alaska and the Pan-Arctic," Global Change Biology, Vol. 12, No. 4, 2006, pp. 686702. http://dx.doi.org/10.1111/j.1365-2486.2006.01128.x

[133] D. K. Swanson, "Three Decades of Landscape Change in Alaska's Arctic National Parks: Analysis of Aerial Photographs, C. 1980-2010,' In: N. P. Service, Ed., Fort Collins, 2013.

[134] K. Joly, R. R. Jandt and D. R. Klein, "Decrease of Lichens in Arctic Ecosystems: The Role of Wildfire, Caribou, Reindeer, Competition and Climate in North-Western Alaska," Polar Research, Vol. 28, No. 3, 2009, pp. 433442. http://dx.doi.org/10.1111/j.1751-8369.2009.00113.x

[135] E. A. Holt and P. Neitlich, "Lichen Inventory Synthesis: Western Arctic National Parklands and Arctic Network, Alaska," National Park Service, Fort Collins, 2010.

[136] K. Joly, F. Stuart Chapin III and D. R. Klein, "Winter Habitat Selection by Caribou in Relation to Lichen Abundance, Wildfires, Grazing, and Landscape Characteristics in Northwest Alaska," Ecoscience, Vol. 17, No. 3, 2010, pp. 321-333. http://dx.doi.org/10.2980/17-3-3337

[137] S. Makkonen, R. S. K. Hurri and M. Hyvärinen, "Differential Responses of Lichen Symbionts to Enhanced Nitrogen and Phosphorus Availability: An Experiment with Cladina Stellaris," Annals of Botany, Vol. 99, No. 5, 2007, pp. 877-884. http://dx.doi.org/10.1093/aob/mcm042

[138] M. Kauppi, "The Influence of Nitrogen-Rich Pollution Components on Lichens," Acta Universitatis Ouluensis, Seris A, Scientiaererum Naturalium, Biologica, Vol. 101, No. 9, 1980.

[139] C. Racine, J. Allen and J. G. Dennis, "Long-Term Monitoring of Vegetation Change Following Tundra Fires in Noatak National Preserve, Alaska," National Park Service, Arctic Network Inventory and Monitoring Program, report NPS/AKRARCN/NRTR-2006/02, 2006.

[140] P. N. Neitlich, J. VerHoef, S. B. Berryman, A. Mines and L. H. Geiser, "Effects of Heavy Metal-Enriched Road Dust from the Red Dog Mine Haul Road on Tundra Vegetation in Cape Krusenstern National Monument, Alas- 
ka," 2013. in press

[141] J. Ford and L. Hasselbach, "Heavy Metals in Mosses and Soils on Six Transects Along the Red Dog Mine Haul Road Alaska," Western Arctic National Parklands National Park Service, 2001.

[142] L. Hasselbach, J. M. Ver Hoef, J. Ford, P. Neitlich, E. Crecelius, S. Berryman, B. Wolk and T. Bohle, "Spatial Patterns of Cadmium and Lead Deposition on and Adjacent to National Park Service Lands in the Vicinity of Red Dog Mine, Alaska," Science of the Total Environment, Vol. 348, No. 1-3, 2005, pp. 211-230. http://dx.doi.org/10.1016/j.scitotenv.2004.12.084

[143] D. H. Landers, S. L. Simonich, D. A. Jaffe, L. H. Geiser, D. H. Campbell, A. R. Schwindt, C. B. Schreck, M. L. Kent, W. D. Hafner, H. E. Taylor, K. J. Hageman, S. Usenko, L. K. Ackerman, J. E. Schrlau, N. L. Rose, T. F. Blett and M. M. Erway, "The Fate, Transport, and Eco- logical Impacts of Airborne Contaminants in Western National Parks (USA); Epa/600/R-07/138," In: US Environmental Protection Agency, Office of Research and Development, NHEERL, Western Ecology Division, Corvallis, 2008.

[144] Arctic Monitoring and Assessment Program (AMAP), "Arctic Pollution Issues: A State of the Arctic Environment Report," Arctic Monitoring and Assessment Programme (AMAP), Oslo, 2004.

[145] Arctic Monitoring and Assessment Program (AMAP), "Arctic Pollution 2011," Arctic Monitoring and Assessment Programme (AMAP), Oslo, Norway, 2011, 38 p.

[146] T. H. DeLuca, O. Zackrisson, M. C. Nilsson and A. Sellstedt, "Quantifying Nitrogen-Fixation in Feather Moss Carpets of Boreal Forests," Nature, Vol. 419, No. 6910, 2002, pp. 917-920. 